\title{
The role of college bound friends in college enrollment decisions by race, ethnicity, and gender
}

\author{
Steven Elías Alvarado \\ Cornell University \\ Citation: \\ Alvarado, S.E. 2021. "The role of college bound friends in college enrollment decisions by race, \\ ethnicity, and gender." American Educational Research Journal.
}

\begin{abstract}
:
This study examines the association between college bound friends and college enrollment using restricted transcript data from the HSLS. Propensity score matching and school fixed effects models suggest that having close college bound friends is positively associated with enrolling in college. However, Black and Latino male students are much less likely to benefit from having college bound friends than others, suggesting that structural and cultural factors that are tied to race, ethnicity, and gender may limit the beneficial potential of friends, especially for these male Black and Latino students. Implications for addressing racial and ethnic disparities in college enrollment and for the role of friends in college enrollment decisions are discussed.

Keywords: College enrollment, friends, race/ethnicity

Acknowledgements: All analyses rely on restricted High School Longitudinal Study data with special permission from the U.S. Department of Education, Institute of Education Sciences, and the National Center for Educational Statistics. The author thanks Anna Haskins and Adam Gamoran for helpful comments and suggestions, Summer Lopez-Colorado for assistance in assembling tables, and various anonymous reviewers for their helpful suggestions. All errors and opinions, however, belong to the author alone.
\end{abstract}


Black and Latino students demonstrate a clear and persistent disparity in their college enrollment rates relative to their White and Asian counterparts (de Brey et al., 2019; Kena et al., 2015). Among the potentially important strategies for improving college enrollment rates for Black and Latino students is improving their access to friendship networks that contain valuable knowledge and information about the college-going process (Laura Walter Perna \& Titus, 2005). Adolescent friendships are crucial for the development and direction of students' educational trajectories (W. Carbonaro \& Workman, 2013, 2016; J. Coleman, 1961; Giordano, 2003; Hallinan \& Williams, 1990; R. M. Hauser et al., 1983; Patacchini et al., 2011). Yet, we know little about whether students can use close college bound friends as assets for college enrollment or whether this association varies by important characteristics such as race, ethnicity, and gender. To this end, this paper examines heterogeneity in the association between having close college bound friends and college enrollment for a nationally representative sample of approximately 24,000 students in the United States. Knowledge about whether friends, perhaps the most important drivers of adolescent behavior, are assets that are beneficial for college enrollment allows for a deeper understanding of the college-going process for Black and Latino students.

Scholars of status attainment have for decades highlighted the role played by friends and other influential actors in predicting educational attainment (Haller \& Portes, 1973; R. M. Hauser et al., 1983; Lin, 1999; Sewell et al., 1969). There now exists evidence for the association between the educational orientation of peers and enrolling in college (Robert Crosnoe \& Muller, 2014; Engberg \& Wolniak, 2010; Holland, 2011; Langenkamp \& Hoyt, 2017a; Massey et al., 2011; Sokatch, 2006) and between peers and educational outcomes while in college (Sacerdote, 2001, 2011; Wolniak \& Engberg, 2010). What is still relatively unknown, however, is whether close friends - which may represent more intimate and influential ties than peers - are associated with the decision to enroll in college (Hallinan \& Williams, 1990). Furthermore, college enrollment decisions may also vary by 
students' characteristics such as race and ethnicity (Acevedo-Gil, 2017; Auerbach, 2004; Engberg \& Wolniak, 2009; Hill, 2008; Langenkamp \& Hoyt, 2017b) or by gender, yet little is known about heterogeneity in the association between close college bound friends and college enrollment by race, ethnicity, or gender (Laura Walter Perna \& Titus, 2005).

The key questions that this paper seeks to answer are: (1) Is having close college bound friends associated with students' likelihood of enrolling in college and (2) If so, does this association vary by race, ethnicity, and gender? Based on previous studies, I expect college bound friends (defined by students' answers directly asking about close friends who intend to go to college) to be positively associated with these outcomes. I also expect that the association between college bound friends and college enrollment varies by race and ethnicity, with Whites benefiting more from having college bound friends. In terms of gender, I expect males to express greater sensitivity to college bound friends than females, especially among Latino students.

Here, I make five contributions to the literature: (1) theoretically distinguishing between peers and friends; (2) analyzing heterogeneity by race and ethnicity; (3) analyzing heterogeneity by gender; (4) analyzing college selectivity; and (5) using a counterfactual causal framework and sensitivity analyses to estimate treatment effects. ${ }^{1}$

\section{Theoretical framework for the influence of friends on college enrollment}

Researchers often distinguish between "friends" and "peers" when examining how assets embedded in students' social context benefits their academic outcomes. Whereas friendships represent affective ties that rest on a foundation of mutually shared expectations of intimacy, trust, reciprocity, and altruism (Call \& Mortimer, 2001; Giordano, 2003), peer relationships (i.e., classmates and other students who are not friends) often do not. Here, I focus on friends because of their potential to influence academic outcomes through the transmission of resources and information 
(W. J. Carbonaro, 1998; W. Carbonaro \& Workman, 2013, 2016; Hallinan \& Williams, 1990; Ream

\& Rumberger, 2008). Because friends influence educational outcomes, including educational expectations (R. M. Hauser et al., 1983), they may be an important asset for students' likelihood of enrolling in college. ${ }^{2}$

Adolescence is an especially salient time in the life course when friends matter a great deal for guiding student behavior (J. Coleman, 1961; Newman \& Newman, 1976). Reciprocity, trust, shared expectations, intimacy, emotional investments, affection, and group enforcement of norms act as conduits for transmitting valuable information and resources between students (J. S. Coleman, 1988; Hallinan \& Williams, 1990; Parsons, 1963). Giordano (2003) outlines three explanations for why close friends may be particularly influential during adolescence. First, constant communication and face-to-face interaction between close friends can enhance the opportunity for friends to influence each other. Second, given that homophily and shared interests are common in student friendship networks (Kubitschek \& Hallinan, 1998), close friends may confer heightened levels of influence. Finally, students will conform to expectations of close friends in order to preserve those most valuable social ties. Close friends are therefore most likely to guide students' behavior because the affective bonds between them increases the trustworthiness and validity of the information that passes between them. Friends are likely to share resources and information with each other given constant contact and closeness in a process of "diffusion” (Payne \& Cornwell, 2007). Diffusion relies on direct ties such as those formed through the bonds of friendship (DiMaggio \& Garip, 2012). Friends not only self-select into friendships based on shared interests and academic performance (Flashman, 2011), but they also become more similar over time and come to influence one another's academic outcomes (Kandel, 1978; Lomi et al., 2011)

Friends may directly encourage and motivate one another to study hard, focus, and remain on a college path throughout high school. ${ }^{3}$ Friends also provide companionship and camaraderie 
that may ease the oftentimes isolating academic path to college during adolescence. Close friends who are also college bound are likely to confer influence on students' college enrollment behavior because of the pervasive social pressure to conform to the normative expectation of attending college.

\section{Previous research on friends and the path to college}

Previous research suggest that friends' characteristics are associated with high school academic performance (R. Crosnoe et al., 2003), advanced course taking (Riegle-Crumb et al., 2006), and college readiness (Author and colleague, 2015). Scholars of education often break down collegegoing into distinct stages: planning, applying, being accepted, and enrolling into college (DesJardins et al., 2006; Grodsky \& Riegle-Crumb, 2010). Among the reasons that friends may be important at the planning, applying, and enrolling stages of the college-going process are that they (1) can create pressures to conform and (2) students may adjust their educational plans after comparing themselves to the plans of their friends. Consequently, friends can fulfill the task of being role models for each other and can construct the normative environment that can signal group expectations and values (Buchmann \& Dalton, 2002; Woelfel \& Haller, 1971). Thus, students may refer to their friends and act accordingly to (1) keep pace with their friends' educational investments and (2) avoid short and long-term marginalization from the group (Sewell et al., 1969). Indeed, friends can have a positive influence on students' high college expectations (W. Carbonaro \& Workman, 2016).

In addition to (and distinct from) friends, scholars have found that high school peers can influence college attendance (Babcock, 2008; Bifulco et al., 2011, 2014; Engberg \& Wolniak, 2010; J. Fletcher, 2013; Mullen, 2010; Palardy, 2013; Perez \& McDonough, 2008; Person \& Rosenbaum, 2006; Wells et al., 2013). ${ }^{4}$ However, Hallinan and Williams (1990) argue that friends may have a stronger impact than peers in the college-going process. Following earlier research (Author and 
colleague, 2015; Author and colleague, 2012; Calvo-Armengol, Patacchini, \& Zenou, 2009; Cherng, Calarco, \& Kao, 2012; R. Crosnoe, Cavanagh, \& Elder, 2003; Hallinan \& Williams, 1990; Langenkamp, 2010; Riegle-Crumb, Farkas, \& Muller, 2006) I focus on friends, rather than peers, because of the direct influence they may have on educational outcomes through strong affective ties. $^{5}$

\section{Race and ethnicity}

Research suggests that race and ethnicity may moderate the association between social context and college-going decisions (Langenkamp \& Hoyt, 2017a; Laura Walter Perna \& Titus, 2005). Still, research on the heterogeneous effects of social context by race and ethnicity remains nascent and mixed (Cheng \& Starks, 2002; J. M. Fletcher, 2011). Two processes - one structural and one cultural - may explain heterogeneity in the associations between social context and educational outcomes.

Among the structurally-rooted processes are stereotype threat, oppositional culture, and neighborhoods. Black and Latino students may underperform academically as a result of stereotypes about their academic ability (Steele \& Aronson, 1995), possibly leading the most high-achieving Black and Latino students (who are presumably considering college) to think as themselves as unworthy of being role models for their friends. Structural discrimination in the wider society may lead to the development of an oppositional culture among Black and Latino students that eschews

an educational system that does not reflect and often marginalizes them (Fordham \& Ogbu, 1986). ${ }^{6}$ This may reduce the ability of college bound friends to influence Black and Latino students if they feel as if such friends would come at the cost of social standing among co-ethnics. Both the supply (stereotype threat) and demand (oppositional culture) of college influencers may then combine to reduce the degree of influence of college bound friends among Black and Latino students. The 
influence of friends may also be tempered among Black and Latino students who grow up in disadvantaged and unsafe neighborhoods due to the development of lack of trust as a survival strategy (Giordano, 2003). Instead of turning to friends, Black and Latino students in these contexts may turn to their families as primary sources of influence (Portes \& Zhou, 1993).

One relevant culturally-rooted process is familism, briefly defined as the cultural preference for placing family goals above individual goals (Moore, 1970; Sabogal et al., 1987; Triandis et al., 1982). Although familism is often tied to Latino immigrant educational processes (Lopez-Turley, 2006; Ovink \& Kalogrides, 2015; Turley et al., 2010), it may also apply to Black students (Giordano et al., 1993; Larson \& Asmussen, 1991; Stack, 1974).

There is an ongoing tension in the literature about whether familism acts to either increase or decrease educational investments. Elements of familism such as strong intimate ties among family members (nuclear and extended), loyalty, obligations, and a sense of familial responsibility may positively impact educational investments by protecting students from deviant peers (Germán et al., 2009) and by providing social and moral support for Latinos embedded in the college choice process (Ceja, 2004, 2006; González et al., 2003). Moreover, familism may be used to increase educational investments if educational institutions can harness and direct the power of influence that families have on Black and Latino students toward educational goals. Given the limited amount of information that parents can provide Latino students, in particular, about college (Ceja, 2006), creating spaces where Latino families and students can gain knowledge and confidence about college together in concert with their intersectional lived experiences and identities through "collegeconocimiento" may lead to increased investments in students' education (Acevedo-Gil, 2017; Auerbach, 2004). Similarly, connecting Black and Latino students' education with narratives about the struggle and oppression in their history could be another way to leverage the influence of friends to improve educational investments (Cammarota, 2004; O’Connor, 1999). 
Familism may also suppress educational investments by placing pressure on students to stay close to home for college. (Desmond \& Turley, 2009; Lopez-Turley, 2006; Ovink, 2014; Ovink \& Kalogrides, 2015; Perez \& McDonough, 2008; Turley et al., 2010). Yet, evidence suggests that it may not be familism per se that deters Latino students from college enrollment, but rather socioeconomic background and prior achievement that explains most of the gap between Latinos' and Whites' college enrollment (Ovink \& Kalogrides, 2015). Moreover, in Latino families where high levels of familism interact with high levels of parental education, students' educational outcomes may actually increase (Valenzuela \& Dornbusch, 1994).

\section{Gender}

Gender may also moderate the association between college bound friends and college-going decisions, however research on this is also nascent and mixed (Riegle-Crumb, 2010; Wells et al., 2013). In particular, despite the fact that females overall report having more academically-focused friendship groups that may lead to higher odds of college matriculation (Riegle-Crumb, 2010), Latina students may face cultural expectations regarding familial obligations that could dim the influence of their high-achieving friends compared to Latino males. ${ }^{7}$ This highlights the way that race, ethnicity, and gender often interact to produce acute forms of inequality. Therefore, my analysis adopts an intersectional approach that seeks to uncover variation in the benefits of having college bound friends by race, ethnicity, and gender (Collins, 2002; Hancock, 2016).

Despite the fact that the Latina population in the U.S. has grown sharply, Latinas remain underrepresented in their college enrollment, retention, and four-year degree completion (de Brey et al., 2019; Otero et al., 2007; Sy \& Romero, 2008). The role of familism in educational decisions may be more acutely felt among Latinas than Latinos (Ovink, 2014). Moreover, given that many Latinos are first-generation college students, Latina students may be especially likely to turn to high school 
counselors for guidance about college (Riegle-Crumb, 2010). Unfortunately, research suggests that Latino students, who may in fact need access to counselors more than others (R. Stanton-Salazar, 1997; R. D. Stanton-Salazar, 2001), are also the least likely to have it (Perez \& McDonough, 2008; Laura W. Perna et al., 2008). Once in college, Latina students report increased responsibilities and expectations to further support the family, despite feelings of increased levels of independence (Sy \& Romero, 2008).

\section{College selectivity}

College selectivity is increasingly becoming a crucial determinant of life-outcomes and a source of stratification along racial and ethnic lines (Alon \& Tienda, 2007; Posselt et al., 2012). Still, high-achieving yet low-income students often do not apply to any selective colleges (Hoxby \& Avery, 2012). The fact that many of these students are also Black and Latino may lead to their underrepresentation at selective and highly selective colleges (de Brey et al., 2019).

Compared to a high school degree, college graduates benefit from increased returns in terms of economic outcomes, health, stable families, and access to advantageous social networks (Hout, 2012). Moreover, students who are the least likely to go to college are the most likely to benefit from doing so (J. E. Brand \& Xie, 2010). Despite similar earnings for enrollment in two and four-year colleges (Kane \& Rouse, 1995), attending any four-year colleges may increase the likelihood of attaining a BA degree (Kane \& Rouse, 1999; Rouse, 1995) and therefore lead to higher levels of occupational prestige, lifetime earnings, and higher levels of health and well-being.

Enrolling in a selective or highly selective four-year college is valuable because of its positive association with well-being in adulthood (Alon \& Tienda, 2005; Jennie E. Brand \& Halaby, 2006; Gerber \& Cheung, 2008; Hout, 2012; Long, 2008; Zhang, 2005). Yet, Latino students are the least likely to enroll in any four-year colleges (Fry, 2011; Hurtado et al., 1997). Latinos who do enroll in 
four-year colleges disproportionately enroll in less selective colleges (Fry \& Taylor, 2013). Still, net of controls, Latinos are more likely than Whites to enroll in more selective colleges (Langenkamp \& Hoyt, 2017a). Given this backdrop, it is important to control for as many variables that may increase the probability of having college bound friends and enrolling in college as possible, especially selective ones, for Black and Latino students.

\section{Causal inference}

Here, I respond to concerns about selectivity that are endemic to the literature on the influence of friends (Durlauf, 2002; Robert M. Hauser, 1970) by using a counterfactual causal framework, propensity score matching (PSM), that matches respondents who did and who did not receive the treatment, having close college bound friends, using a host of theoretically driven observed characteristics from the High School Longitudinal Study (HSLS). Given that matching models are only as good as the variables that go into them (Cook et al., 2009; Heckman, 2005; S. L. Morgan \& Harding, 2006a; P. Rosenbaum, 2002; Shadish et al., 2002a), I also invoke a formal sensitivity analysis to address threats from an unobserved confounder and I control for unobserved confounders at the school level using school fixed effects.

Still, the problem of reflection, whereby the outcomes of two friends affect each other simultaneously, threatens to render estimates spurious (Manski, 1993). The reflection problem arises when regressing outcomes on outcomes such as test scores of a respondent on the test scores of her friend. Here, I am not comparing outcomes of respondents to outcomes of friends. Instead, I am using the expectations of friends to predict behaviors of respondents. This distinction perhaps limits threats from reflection given that friends' expectations and students' eventual behaviors are at least somewhat different. Still, my analysis would be strengthened by direct measures of friends' expectations, rather than respondents' interpretations of friends' expectations, regardless of the 
ability of friendship bonds to provide accurate estimates of friends' plans. That is, my predictor may represent respondents' endogenous preferences for like peers (McPherson et al., 2001), thereby making my measure of friends simply a measure of homophily. Despite my efforts to adjust for factors that may affects friendship selection based on shared interests and academic performance, these data are simply unable to completely adjudicate between homophily and friends - therefore warranting caution when interpreting my results as causal.

\section{Data}

I use restricted transcript data from the HSLS of 2009, an ongoing nationally representative survey of approximately 24,000 students nested within 944 public and private high schools who were in the $9^{\text {th }}$ grade in the fall of 2009. The Institute of Education Sciences, U.S. Department of Education administers the HSLS. The HSLS collected data from parents and school administrators about sociodemographic, academic, and school-level characteristics in the fall of the $9^{\text {th }}$ grade.

Subsequently, students, parents, and administrators were interviewed in the spring of $11^{\text {th }}$ grade. HSLS fielded an update in the fall of 2013, immediately after scheduled high school graduation, to obtain information about postsecondary behaviors and high school achievement data from transcripts.

The HSLS is especially useful in answering the questions I have raised because of the rich information it contains on $8^{\text {th }}$ grade achievement, $9^{\text {th }}$ and $11^{\text {th }}$ grade sociodemographic, academic and school characteristics, transcript data on coursework and achievement, data on college application and financial aid, as well as data on close college bound friends in high school and college enrollment. These data are arguably the ideal data set to study college outcomes among the most recent cohort of college students across the U.S. The HSLS also provides key methodological advantages in terms of both the longitudinal design and national representativeness. Missing data 
ranged from 0.05 percent to 9.66 percent. Rather than drop cases with missing values, I imputed missing data using the ice command in Stata (Allison, 2002; von Hippel, 2007). I round all sample sizes in accordance with National Center for Educational Statistics (NCES) guidelines for analyzing restricted data.

\section{Close college bound friends}

The treatment variable is a binary $(0,1)$ indicator for whether students had close college bound friends $(\mathrm{CBF})$ in the spring of $11^{\text {th }}$ grade. That is, the HSLS asked students: "How many of your close friends plan to attend a 4 year college?” Although I cannot distinguish between the level of closeness (e.g., best, second best, etc.), the HSLS question is explicitly asking about close friends and not mere acquaintances. Students could choose from the following four options: Less than half, about half, more than half, and all of them. I operationalized $\mathrm{CBF}$ as having at least 51 percent close friends who planned to attend a 4 year college (i.e., those who answered more than half or all of them). Therefore, students received a 1 on the binary indicator if they answered that either more than half or all of their close friends planned to attend a 4 year college and a 0 if they answered that less than half or about half of their close friends planned to attend a 4 year college. CBF reflects respondents' own understanding of the college-going expectations of their close friends.

\section{College enrollment}

The four outcomes I analyze represent students' self-reported college enrollment that HSLS measured during the fall of 2013. The first outcome indicates whether students enrolled in any college (e.g., less than 2 year, 2 year, or 4 year). Students were coded 1 if they were in any college and 0 if they were not in any college in the fall of 2013. That is, the first outcome contrasts students in any level of college versus those who were not in college. The second outcome indicates whether 
students were in a 4 year college (coded 1) versus if they were in a less than 2 year or in a 2 year college (coded 0$)$. That is, the second outcome contrasts students who were in a 4 year college to those who were in college but not in a 4 year college.

The third and fourth outcomes refer to the selectivity level of the 4 year college that students were enrolled in. That is, students were first asked about which specific 4 year college they were enrolled in and then the NCES later assigned selectivity rankings to the college that students named using Integrated Postsecondary Education Data System (IPEDS) selectivity rankings for those colleges. Specifically, the third outcome indicates whether students were enrolled in a selective 4 year college. Students were coded 1 if they were enrolled in a) a highly or b) a moderately selective 4 year college and 0 if they were enrolled in c) an inclusive 4 year college or d) a 4 year college whose selectivity was unclassified. The fourth outcome indicates whether students were enrolled in a highly selective 4 year college. Students were coded 1 if they were enrolled in a highly selective 4 year college and 0 if they were enrolled in e) a moderately selective 4 year college, f) an inclusive 4 year college, or g) a 4 year college whose selectivity was unclassified. ${ }^{8}$

\section{Covariates}

Means and standard deviations for all variables are broken down by race-ethnicity in Table 1 . I include $8^{\text {th }}, 9^{\text {th }}$, and $11^{\text {th }}$ grade covariates in this analysis that account for achievement, sociodemographic background, college expectations, and school climate. I also include transcript data on grade point average, ACT and SAT scores, and any financial aid students received for college that NCES collected in fall 2013. Collectively, these covariates are important to include in this analysis because of their ability to predict CBF as well as the college enrollment outcomes.

[Table 1 about here] 
Specifically, I account for students' academic interest and achievement with a dichotomous indicator of whether the student took an advanced math or science course in the $8^{\text {th }}$ grade, a dichotomous indicator of whether students received an $\mathrm{A}$ or $\mathrm{B}$ in $8^{\text {th }}$ grade science or math course grade, and continuous measures of $9^{\text {th }}$ and $11^{\text {th }}$ grade math test scores. I also include a dichotomous indicator for whether students have an educational or career plan and whether students are sure they will go to college as well as indicators for the level of education that parents expect for their children.

Further, given previous research on the influence of classmates and school climate on educational outcomes, I include a vector of covariates that address the socioeconomic and academic climate of the school. These covariates also address structural arrangements in schools that may affect college enrollment. For example, I include continuous measures of the percent of students receiving free or reduced priced lunch, the percent of students taking AP courses, the number of certified full-time math and science teachers, dichotomous indicators of whether the school offers advanced science and math courses (i.e., AP calculus AB/BC, computer science, AP computer science A, AP computer science A, AP computer science AB, Advanced/II/AP/IB biology, Advanced/II/AP/IB chemistry, Advanced/II/AP/IB physics), whether the school requires completion of specific math or science courses for graduation, and a scale for whether the school has a pro-science climate. ${ }^{9}$ All of these school-level covariates are measured in the $9^{\text {th }}$ grade. Finally, I include a covariate for whether the school uses a tracking policy to place students in $9^{\text {th }}$ grade courses.

\section{Methods}


Following the counterfactual causal framework (S. L. Morgan \& Harding, 2006b; Stephen L. Morgan \& Winship, 2014a; Shadish et al., 2002b), the "effect" is defined as the difference in outcome between the scenario in which an individual has $\mathrm{CBF}$ and the counterfactual scenario in which a similar individual does not have CBF. I estimate students' propensity to have CBF conditional on achieving proper covariate balance using observed characteristics. To be clear, the estimates I present are not strictly causal.

Specifically, I used PSM, as developed by Rosenbaum and Rubin (P. Rosenbaum \& Rubin, 1983b; D. Rubin, 1974, 1980; D. B. Rubin, 1978). Previous scholars have summarized the strengths and weaknesses of this approach for estimating effects in the absence of randomized data (Becker \& Ichino, 2002; M. Caliendo \& Kopeinig, 2008; Stuart \& Rubin, 2008). I compared students with CBF with the control group of students without $\mathrm{CBF}$ and estimated the average treatment effect on the treated (ATT). I chose the ATT because I am primarily interested in the treatment effect on those for whom the treatment is intended (Heckman et al., 1997). Caliendo and Kopeinig (2008) further discuss the utility of the ATT over the ATE when using propensity score matching. Moreover, in regards to propensity score matching, Morgan and Winship (2014b, p. 173) argue that "the only target parameter that can be estimated with any degree of confidence is the ATT." For further discussion of the primacy of the ATT in propensity score matching, see Austin (2011) and Imbens (2004).

The strength of matching lies in its ability to reduce the role of observed covariates on any remaining differences between students who had $\mathrm{CBF}$ and students who did not have CBF after matching if selection into treatment depends exclusively on observed variables (D'Agostino, 1998). ${ }^{10}$ The benefits of matching over traditional regression are that matching 1) allows for the explicit assessment of covariate balance to minimize bias between treatment and control groups; 2) it is nonparametric; and 3) it allows for the formal testing of confoundedness in treatment effects (M. 
Caliendo \& Kopeinig, 2008; Heckman et al., 1998). The drawbacks of PSM are that 1) it only addresses selection on observed variables (allowing bias from selection on unobserved variables to remain) and 2) it does little to address simultaneity bias (e.g., where students are friends because they are both college bound, drawing into question whether their friends' college boundedness can affect college outcomes). I explicitly address the first drawback through a formal sensitivity analysis. The second, however, largely remains a limitation of the current study. To be clear, the PSM technique is not better than the variables that go into it (S. L. Morgan \& Harding, 2006a; P. Rosenbaum, 2002; Shadish et al., 2002b). Also, other data sets, such as Add Health, identify friends and would therefore facilitate the calculation of the predicted likelihood that friends are college bound; however, Add Health is more limited in its educational data. Unfortunately, the HSLS does not identify specific friends.

First, I select the covariates upon which the matching will be based (Augurzky \& Schmidt, 2001). I compiled a vector of variables that is based on the relevant literature that would conceivably predict treatment assignment as well as impact the outcomes. ${ }^{11}$ Table 1 lists the vector of covariates I used for matching save for the treatment and outcomes. I entered all covariates into the selection model as main effects. Second, I estimate the predicted probability of receiving the treatment by calculating the propensity score using a logit model (Leuven \& Sianesi, 2003) and then I match individuals who had similar propensities to have CBF through kernel matching. ${ }^{12}$ All analyses are restricted to observations that fell in the region of common support (M. Caliendo \& Kopeinig, 2008). Third, I evaluate whether the groups being compared have equal (or sufficiently balanced) distributions of relevant observed covariates (Dehejia, 2005). I evaluated balance by inspecting preand post-matching standardized bias scores for variables in the aggregate as well as individually.

Finally, I compare the outcomes of the respondents in the treatment and control groups. I compare the propensity score model treatment effects across racial and ethnic groups by invoking a 
post-hoc difference in means test that are recommended by Paternoster et al. (1998, see equation 4). A key limitation of the propensity score matching technique lies in its inability to reduce the bias in estimated treatment effects that stems from unobserved confounders that affect both treatment assignment as well as the outcome (Stuart \& Rubin, 2008). As a result, I conducted a formal sensitivity analysis (see Appendix A for details) of the statistically significant ATTs. Shadish et al. (2002b, p. 165) write that " $[\mathrm{w}]$ hen sensitivity analysis is combined with matching on propensity scores, these new statistical developments provide an important new analytic tool in the arsenal of quasi-experimentation.”

\section{Results}

Unadjusted interaction models

Appendix B demonstrates results from unadjusted logistic regression interaction models of having college bound friends and race and ethnicity run first for all students and then run separately by gender. These results demonstrate the total differences between the race and ethnic impacts of CBF for all students, then for females, and then for males.

At first glance, the results for all students suggest that all Black and Latino students (males and females) benefit less than White and Asian students from CBF for all four outcomes. However, upon closer inspection of the separate impacts of CBF for females and males, a slightly different picture emerges. That is, the gender-specific results suggest that both race and ethnicity and gender may play a role in the effect of having college bound friends. These racial and ethnic - gender differences highlight the potential for intersectional variation in the benefits students accrue from having $\mathrm{CBF}$. For instance, the impact of $\mathrm{CBF}$ on enrolling in any college appears to be even smaller for Black and Latino male students compared to their co-ethnic female counterparts. This pattern of Black and Latino males benefiting less from CBF than their co-ethnic female counterparts persists 
throughout almost all the models (save for Black females and males enrolling in a selective college). In fact, in many of the models, Black and Latina female show no statistically significant difference compared to White co-gender students in the impact of CBF. These results provide a coarse foundation that will serve as the basis for the more rigorous PSM models.

Propensity score models: Race and ethnicity

Table 2 summarizes results from the propensity score models that match students who had $\mathrm{CBF}$ with those who did not, based on their similar observed propensity to have a CBF after adjusting for all the covariates in Table 1. The table distinguishes across racial and ethnic subgroups by rows and across college enrollment outcomes by columns. For each racial and ethnic subgroup and for each outcome, I provide information in regards to not only the ATT, but also the standard error, t-statistic, the number of untreated and treated respondents in the region of common support (i.e., the area of propensity scores wherein matches were made), the number of treated off support, as well as the mean standardized bias prior to matching and after matching.

The first finding is for the performance of the propensity score model to improve the quality of the treatment and control matches. Table 2, demonstrates a clear decrease in the bias after matching (i.e., suggesting an improved 'apples to apples' comparison than traditional regression) based on observed characteristics. That is, the PSM model's achieved post-matching bias score comes very close to the theorized absolute 0 mean bias level, which would suggest that treatment and control cases that the PSM is comparing are as similar as possible based on observed covariates. While there is no standardized threshold for post-matching bias in the literature, a post-matching bias of approximately 5 percent is generally viewed favorably (M. Caliendo \& Kopeinig, 2008). Figure 1 further demonstrates an improvement in balance (i.e., the post-matching moves toward the center line [0 percent bias]) for each of the observed covariates individually for all students. 
[Figure 1 about here]

Examining the ATTs for all students combined suggests that CBF increases the probability of enrolling in any college by 6 percentage points, enrolling in a 4 year college by 10 percentage points, enrolling in a selective 4 year college by 3 percentage points, and enrolling in a highly selective 4 year college by 7 percentage points. However, after examining the AT'Ts by race and ethnicity, there are differences in the degree of impact that CBF has on college enrollment decisions. For example, when examining the first outcome, enrolling in any college, White, Asian, and Black students benefit from CBF by 7, 8, and 4 percentage points, respectively. However, Latino students' enrollment in any college does not appear to benefit from CBF. Moreover, post-hoc difference in means tests (Paternoster et al., 1998) suggest that the benefits for Asian students and Black students are each statistically indistinguishable from the benefits for White students $(\mathrm{p}<0.05)$. This suggests that while White, Asian, and Black students benefit from CBF in terms of their likelihood of enrolling in any college, Latino students do not.

With regard to enrolling in a 4 year college, the results suggest that White, Asian, Black, and Latino students indeed benefit from $\mathrm{CBF}$ by $10,7,8$, and 12 percentage points, respectively. Posthoc difference in means testing also reveals that the benefits for Asian students, Black students, and Latino students are not statistically distinguishable from the benefits for White students. Therefore, it appears that all students benefit from CBF to an equal degree in terms of their likelihood of enrolling in a 4 year college.

However, in regards to enrolling in a selective 4 year college, only White students appear to benefit from CBF by 4 percentage points. Asian, Black, and Latino students do not appear to benefit from $\mathrm{CBF}$ in terms of enrolling in a selective 4 year college. Finally, in terms of enrolling in a highly 
selective 4 year college, only White students and Asian students appear benefit from CBF by 7 and 8 percentage points, respectively. Moreover, their estimates for CBF are statistically equivalent.

Propensity score models: Gender

Appendices C and D summarize the results for female and male students (both by race and ethnicity), respectively. These results sufficiently convey the main findings of this paper: not only do race and ethnicity matter for the influence of $\mathrm{CBF}$, but so does gender. Further, echoing the results from the unadjusted interaction effects models, the PSM models demonstrate that males do not benefit as much as females do from CBF. Appendix D demonstrates that Black and Latino males benefit from CBF far less than their male White and Asian counterparts do. In fact, in only one instance do Black and Latino male students benefit at all from CBF - that is, CBF increases the probability of four-year college enrollment for Latino males by 10 percentage points. Otherwise, Black and Latino males do not benefit at all from CBF.

Meanwhile, Appendix C demonstrates that among female students, Black and (especially) Latina students benefit from CBF in their college enrollment outcomes. For example, Black females' probability of enrolling in any college increases as a function of $\mathrm{CBF}$ by 9 percentage points. However, Black females do not benefit in terms of any of the other more selective, and perhaps more socioeconomically advantageous, college enrollment outcomes. Moreover, Latina females benefit from CBF not only for enrolling in any college but also for enrolling in a four year college and for enrolling in a selective college (and all three of these effects are statistically equivalent to those of female White students). Neither female nor male Black and Latino students benefit from $\mathrm{CBF}$ in terms of enrolling in a highly selective college. Moreover, only female White and female Asian students benefited from CBF in terms of enrolling in highly selective colleges. 
The only findings that I can compare between females and males are those for the benefits of $\mathrm{CBF}$ on enrolling in a four year college. Post-hoc significance testing reveals that these effects are statistically indistinguishable. That is, female and male Latino students benefit from CBF to a similar degree in terms of enrolling in a four-year college. In general, the gender analyses reveal that CBF mainly impact White and Asian students, leaving Black and Latino female and (especially) male students without as much to gain from membership in these college-going friendship networks.

Sensitivity analysis

Although the sensitivity analysis is no panacea for selection bias, I test the robustness of the ATTs to incremental erosions of the ignorability assumption (DiPrete \& Gangl, 2004; P. Rosenbaum \& Rubin, 1983a). ${ }^{13}$ This sensitivity analysis for PSM is limited, however, in that it only detects the impact of a single unobserved confounder on the treatment effect. Table 3 summarizes the results from the sensitivity analysis. I report the sensitivity analysis on the results from Table 2 (female and male students combined) because the gender-specific results are subsumed within this general sensitivity analysis. ${ }^{14}$ Appendix E summarizes the detailed results of the sensitivity analysis.

\section{[Table 3 about here]}

While suggestive of robust treatment effects, the sensitivity analysis alone does little to build confidence in the ATTs. To that end, I compare the sensitivity analysis results with observed covariates to get a sense of what kind of variable must be lurking unobserved to render my results null. Appendix F summarizes the results from separate selection models that predict CBF based on observed covariates. Comparing each of the 'killer' confounders with observed covariates that I have already included in the propensity score matching model gives some confidence that the results may 
be qualitatively robust to unobserved bias. Even the least robust result (i.e., the benefit of CBF on enrollment in any college among Black students) suggests that researchers must find an as of yet unobserved covariate that has the same impact as being in poverty to undermine my result. Indeed, it may be difficult to imagine a variable that I have not yet included that is 1) as strong as or stronger than the observed covariates; 2) perfectly predicts the outcome; and 3) can affect selection to the point of undermining the treatment effects.

Alternative bandwidth robustness check

As a second method of testing the robustness of the treatment effects, I supplement the results in Table 2 with results from models that decrease the number of individuals in the control group I use to construct the counterfactual outcome vis à vis the weighted averages in kernel matching. ${ }^{15}$ Table 4 summarizes the treatment effects after contracting the bandwidth to 0.03 , yielding a smaller and more similar (in terms of propensity scores) group of controls with which to match to treated respondents. This exercise has the advantage of improving the 'apples to apples' comparison, but also the disadvantage of a less smooth estimated density function, decreased fit, and increased variance between the estimated and the true underlying density function (M. Caliendo \& Kopeinig, 2008).

[Table 4 about here]

As expected, Table 4 demonstrates that decreasing the bandwidth parameter by a factor of 3 improves the comparisons between treated and non-treated respondents, as evidenced by the decreases in levels of mean post-matching bias. However, the qualitative change to a more stringent set of comparison groups did alter the findings somewhat. For instance, Table 4 demonstrates that 
CBF no longer benefits enrolling in 4 year or highly selective colleges among Asian students.

Although the standard errors did not change much, the coefficients changed enough to render these associations null. Among Black students, the change in bandwidth also erased the benefit of CBF on enrolling in any college. Once again, a change in the coefficient size caused the AT'T to disappear. Nevertheless, among Whites and Latinos, there was no significant overall impact on the estimated associations, despite decreasing the bandwidth from 0.09 (Table 2) to 0.03 (Table 4).

Alternative specification of $\mathrm{CBF}$ robustness check

Previously, the treatment indicates whether a student had $51 \%$ of close friends who were college bound or not. Alternatively, I created a second treatment variable that indicated whether all of the student's close friends were college bound. Table 5 summarizes the results from the models that use the alternative CBF specification for the gender-neutral sample. ${ }^{16}$ Despite racial and ethnic heterogeneity in the number of college enrollment outcomes that CBF positively affects, every racial and ethnic group benefits from $\mathrm{CBF}$ in at least one college enrollment outcome. The overall pattern of results and conclusions of this analysis, therefore, are generally robust to alternative specifications of the treatment indicator.

[Table 5 about here]

School fixed effects

Previous research suggests that including school fixed effects may substantially limit bias from selection into friendships (Calvo-Armengol et al., 2009). ${ }^{17}$ Appendix G summarizes logistic regression models with school fixed effects (FE) to address single and multiple-variable unobserved confounding at the level of the school. Overall, the school FE findings suggest that (1) there continue to be CBF benefits net of unobserved school-level confounders and (2) the benefits of 
$\mathrm{CBF}$ continues to vary by race and ethnicity, generally showing stronger CBF benefits for White students. These findings from the school FE models in Appendix G are in line with those from the PSM models in Table 2. However, when comparing the results from the school FE models to those from the PSM models, one must note that the sample comparisons are restricted to schoolmates in the school FE models and the sample comparisons are restricted to those on the region of common support in the PSM models. This may lead to some discrepancy in the findings.

Appendix H summarizes PSM models with school fixed effects added to the list of covariates included in the PSM models that Table 2 summarizes. The results in Appendix $\mathrm{H}$ demonstrate that among all students, CBF benefits all college enrollment outcomes except for selective college enrollment. This contrasts with the PSM results in Table 2 (that did not have school FE) where $\mathrm{CBF}$ had a positive association with all college enrollment outcomes. It appears that unobserved school confounders explained away the association with enrolling in a selective college. For White students, the addition of school dummies to the PSM models did not alter the main conclusion - CBF has a positive association with applying to every type of college. For Asian students, it appears that unobserved school confounders explained away all the associations leaving CBF without any statistically significant benefits on college enrollment outcomes. For Black students, the association for CBF remained intact for applying to any college, but unobserved school confounders explained away the association with applying to a four-year college. However, Appendix $\mathrm{H}$ also demonstrates that $\mathrm{CBF}$ does positively benefit enrolling in a highly selective college once the PSM model adjusts for unobserved school confounders. Finally, for Latino students, the results do not change at all - $\mathrm{CBF}$ continues to have a positive benefit on enrolling in a four year college, net of unobserved school confounders. In general, the PSM results with additional adjustments for unobserved time-invariant school-level confounders changed the main conclusions 
very little. That is, White students continue to benefit the most from college bound friends while non-White students benefit much less.

\section{Traditional OLS}

The results from PSM may yield similar results as traditional OLS, controlling for the same covariates (Bifulco, 2012; Cook et al., 2008; Guarino et al., 2014; Shadish et al., 2002b, 2008). Further, often one may more easily interpret results from OLS models (Wooldridge, 2005). To test for the similarity between the PSM results in Table 2 and OLS, I run supplementary analyses using conventional OLS regression for models stratified by race and ethnicity (see Appendix I) and models with interaction effects for the moderating effect of race and ethnicity on the association between $\mathrm{CBF}$ and college enrollment (see Appendix J). The results from the OLS analyses largely align with the PSM results. One source of variation in the results is the fact that the PSM analysis restricts the sample to those on the region of common support and to those within the specified bandwidth.

\section{Conclusion}

Theory and empirical research suggest that assets embedded in students' social contexts may yield positive educational benefits in the college-going process. This paper demonstrates that having college bound friends is positively associated with enrolling in any college, 4-year colleges, selective colleges, and highly selective colleges. This paper further demonstrates that race, ethnicity, and gender moderate these associations, provides estimates that are robust to unobserved confounding and alternative model specifications, and capitalizes on longitudinal and restricted transcript data. This paper demonstrates that assets such as information and resources nested within friendships based on trust, and reciprocity can yield statistically significant positive benefits for college enrollment. 
The findings of a positive association between $\mathrm{CBF}$ and college enrollment outcomes align with theory on the influence of friends (J. S. Coleman, 1988; Giordano, 2003; Parsons, 1963) and demonstrate that students indeed reap benefits to being embedded in social networks that are based on close, intimate ties and are potentially rich in knowledge and resources about the college-going process. These results also align with those of Hallinan and Williams (1990) who found that friends were instrumental in the college-going process and with more recent research (W. Carbonaro \& Workman, 2016; Cherng et al., 2012). The findings are also in line with recent findings on the role of peers on educational outcomes (Bifulco et al., 2011, 2014; J. M. Fletcher, 2011, 2012; J. M. Fletcher \& Tienda, 2009).

The findings for limited benefits for college bound friends among Black and Latino students align with previous research for various college-going outcomes (Steven Elias Alvarado \& An, 2015; Steven Elias Alvarado \& Turley, 2012; Langenkamp \& Hoyt, 2017a; Laura W. Perna et al., 2008). Related, previous research also finds that Latino and Black students are often nested in social networks that are low on information and resources regarding college-going (Perez \& McDonough, 2008; Person \& Rosenbaum, 2006).

The findings suggest that structural and cultural forces may partially suppress the benefits of friends for Black and Latino students. For example, residence in neighborhoods where non-kin intimate ties are fleeting, or where those ties may even place pressure on students to participate in dangerous activities, may erode the benefits of friends, favoring family influences instead (Germán et al., 2009; Giordano, 2003; Portes \& Zhou, 1993). Furthermore, stereotype threat and oppositional culture may affect the supply and demand, respectively, of students who do not resist the educational system for Black and Latino male students, thus limiting the influence of CBF (Fordham \& Ogbu, 1986; Steele \& Aronson, 1995). Black and Latino students are also put in less advanced courses in schools and are therefore less likely to be around students who may be on a college 
pathway (Darity et al., 2001; Klopfenstein, 2004; Ndura et al., 2003). Further, Black and Latino students are more likely to be disciplined, suspended, placed in special education, and expelled from school (Diamond \& Lewis, 2015) - all of which suggest that strong structural forces impede their ability to use friends as assets in the college-going process. Cultural frames may also limit the benefits of friends for Black and Latino students. For example, familism, regardless of whether it has a positive (Germán et al., 2009) or negative (Turley et al., 2010) impact on educational outcomes for Black and Latino students, may also suppress the benefits of friends, even if those friends are college bound. That is, some students may be more likely to turn to family over friends or be more likely to weigh the advice they receive from families more heavily when it comes to decisions about college. To be clear, my results do not explicitly demonstrate that any of these mechanisms neighborhoods, stereotype threat, oppositional culture, or familism - are explaining my results. Given the difficulty of school actors to change structural conditions that Black and Latino students are exposed to, college preparatory initiatives could treat the rich cultural frames (e.g., familism) that Black and Latino families bring to bear in the college-going process as assets. In addition to potentially increasing Black and Latino college enrollment by capitalizing on any given increase in the pro-college influence of the family (Acevedo-Gil, 2017), such an approach could also increase the benefit of co-ethnic college bound friends; thereby enhancing the pro-college orientation of the entire community of influence surrounding these students.

The findings from the current study somewhat contrast with expectations that Latina females may benefit less from CBF due to familial influences (Desmond \& Turley, 2009; LopezTurley, 2006). That is, I find that Latina females benefit more from CBF than Latino males do, which aligns with Riegle-Crumb and colleagues' (2010) findings that Latinas have more academically-oriented friends than Latinos do. Policies that aim to increase college enrollment for Black and Latino males may consider structural factors that may lead to patterns of academic 
underperformance (Fordham \& Ogbu, 1986; Massey et al., 2011; Owens \& Massey, 2011; Steele \& Aronson, 1995). My findings also support Riegle-Crumb and colleagues' (2010) findings regarding gender heterogeneity and contrast with Wells and colleagues' (2013) findings.

The findings for college selectivity, where neither Black nor Latino students demonstrate statistically significant benefits for college bound friends, are particularly striking. Given the enhanced returns to selective college attainment, there is reason for concern regarding the limited ability of college bound friends to increase enrollment in these institutions for Black and Latino students.

This analysis is not without its limitations. For example, this study does not claim to find strictly causal effects of $\mathrm{CBF}$ on college enrollment outcomes. Another limitation is the fact that the HSLS does not identify specific characteristics of friends, limiting the ability to calculate predicted likelihoods that friends are college bound to address issue of simultaneity. It is also important to consider that variation may exist in the ability of educational expectations to translate to educational gains by race and ethnicity and by gender. For example, despite increases in students' expectations to attain a college degree (J. Reynolds et al., 2006) and the decline of the association between social background (e.g., parents' education) and college expectations (Goyette, 2008), scholars have found that Black and especially Latino students have become increasingly less likely to realize their plans to attain a college degree than White students (J. R. Reynolds \& Johnson, 2011). Meanwhile, females have been able to make gains on males in being able to translate their expectations to college degree attainment. Although not about expectations of friends, the results from these studies may be relevant in that Black and Latino students (to the extent that they have co-ethnic friends) may not benefit as much as Whites from CBF because their friends, even though college bound, may lack the resources to translate college educational expectations into college educational attainment equally as Whites. This finding of the differential success of college expectations to translate to college 
attainment by race and ethnicity from previous research is in line with my findings. Finally, given that neighborhoods affect educational and many other aspects of well-being across the life course (Steven Elías Alvarado, 2016a, 2016b, 2018, 2019, 2020; Sharkey \& Faber, 2014) future research should examine how neighborhoods stratify access to (and the benefits students accrue from having) college bound friends.

Overall, the findings from this paper suggest that college preparatory initiatives should recognize the nonlinearities in the relationship between college bound friends and college enrollment by race, ethnicity, and gender. The benefits of college bound friends for college enrollment are less for Black and Latino students than for White and Asian students, especially for males and especially for selective and highly selective colleges. College preparatory initiatives may be most successful at enrolling higher numbers of Black and Latino students if they recognize and capitalize on the wealth that is nested within diverse cultural frames and approaches to educational investments (Acevedo-Gil, 2017; Auerbach, 2004; Gamoran et al., 2012; Langenkamp \& Hoyt, 2017b; Laura Walter Perna \& Titus, 2005). It is important to continue to study the impact of friends on educational outcomes if scholars are to inform policy on how to best address educational inequalities. Initiatives aimed at integrating primary and secondary schools that are coupled with deep commitments to fostering interactions that lead to friendship formation may facilitate opportunities for Black and Latino students to benefit more from college bound friends. Further, if family is particularly important for some students, then school personnel should reconsider college access to include families in more meaningful ways. Friendships, perhaps when combined with a culturally-sensitive approach to college-going, may be one essential piece of the puzzle that is necessary to ameliorate racial and ethnic disparities in college enrollment. 


\section{References}

Acevedo-Gil, N. (2017). College-conocimiento: Toward an interdisciplinary college choice framework for Latinx students. Race Ethnicity and Education, 20(6), 829-850. https://doi.org/10.1080/13613324.2017.1343294

Ainsworth-Darnell, J. W., \& Downey, D. B. (1998). Assessing the oppositional culture explanation for racial/ethnic differences in school performance. American Sociological Review, 63(4), 536553.

Alemán, M., \& M, A. (2000). Race Talks: Undergraduate Women of Color and Female Friendships. The Review of Higher Education, 23(2), 133-152. https://doi.org/10.1353/rhe.2000.0006

Allison, P. (2002). Missing Data (Vol. 136). Sage Publications.

Alon, S., \& Tienda, M. (2005). Assessing the "Mismatch" Hypothesis: Differences in College Graduation Rates by Institutional Selectivity. Sociology of Education, 78(4), 294-315. https://doi.org/10.1177/003804070507800402

Alon, S., \& Tienda, M. (2007). Diversity, Opportunity, and the Shifting Meritocracy in Higher Education. American Sociological Review, 72(4), 487-511. https://doi.org/10.1177/000312240707200401

Alvarado, Steven Elías. (2016a). Neighborhood disadvantage and obesity across childhood and adolescence: Evidence from the NLSY children and young adults cohort (1986-2010). Social Science Research, 57, 80-98. https://doi.org/10.1016/j.ssresearch.2016.01.008

Alvarado, Steven Elías. (2016b). Delayed Disadvantage: Neighborhood Context and Child Development. Social Forces, 94(4), 1847-1877. https://doi.org/10.1093/sf/sow020

Alvarado, Steven Elías. (2018). The impact of childhood neighborhood disadvantage on adult joblessness and income. Social Science Research, 70, 1-17. https://doi.org/10.1016/j.ssresearch.2017.10.004

Alvarado, Steven Elías. (2019). The indelible weight of place: Childhood neighborhood disadvantage, timing of exposure, and obesity across adulthood. Health \& Place, 58, 102159. https://doi.org/10.1016/j.healthplace.2019.102159

Alvarado, Steven Elías. (2020). The Complexities of Race and Place: Childhood Neighborhood Disadvantage and Adult Incarceration for Whites, Blacks, and Latinos. Socius, 6, 2378023120927154. https://doi.org/10.1177/2378023120927154

Alvarado, Steven Elias, \& An, B. P. (2015). Race, Friends, and College Readiness: Evidence from the High School Longitudinal Study. Race and Social Problems, 7(2), 150-167. https://doi.org/10.1007/s12552-015-9146-5

Alvarado, Steven Elias, \& Turley, R. N. L. (2012). College-bound friends and college application choices: Heterogeneous effects for Latino and White students. Social Science Research, 41(6), 1451-1468.

Arpino, B., \& Mealli, F. (2008). The specification of the propensity score in multilvel observational studies: Vol. Working Paper No. 6.

Auerbach, S. (2004). Engaging Latino Parents in Supporting College Pathways: Lessons From a College Access Program. Journal of Hispanic Higher Education, 3(2), 125-145. https://doi.org/10.1177/1538192703262514

Augurzky, B., \& Schmidt, C. (2001). The Propensity Score: A Means to an End.

Austin, P. C. (2011). An Introduction to Propensity Score Methods for Reducing the Effects of Confounding in Observational Studies. Multivariate Behavioral Research, 46(3), 399-424. https://doi.org/10.1080/00273171.2011.568786

Babcock, P. (2008). From Ties to Gains? Evidence on Connectedness and Human Capital Acquisition. Journal of Human Capital, 2(4), 379-409. https://doi.org/10.1086/596554 
Becker, S. O., \& Ichino, A. (2002). Estimation of Average Treatment Effects Based on Propensity Scores. The STATA Journal, 2(4), 358-377.

Bifulco, R. (2012). Can Nonexperimental Estimates Replicate Estimates Based on Random Assignment in Evaluations of School Choice? A Within-Study Comparison: Can Nonexperimental Methods Replicate Random Assignment? Journal of Policy Analysis and Management, 31(3), 729-751. https://doi.org/10.1002/pam.20637

Bifulco, R., Fletcher, J. M., Oh, S. J., \& Ross, S. L. (2014). Do high school peers have persistent effects on college attainment and other life outcomes? Labour Economics, 29, 83-90. https://doi.org/10.1016/j.labeco.2014.07.001

Bifulco, R., Fletcher, J. M., \& Ross, S. L. (2011). The Effect of Classmate Characteristics on Postsecondary Outcomes: Evidence from the Add Health. American Economic Journal: Economic Policy, 3(1), 25-53. https://doi.org/10.1257/pol.3.1.25

Brand, J. E., \& Xie, Y. (2010). Who Benefits Most from College? Evidence for Negative Selection in Heterogeneous Economic Returns to Higher Education. American Sociological Review, 75(2), 273-302.

Brand, Jennie E., \& Halaby, C. N. (2006). Regression and matching estimates of the effects of elite college attendance on educational and career achievement. Social Science Research, 35(3), 749_ 770. https://doi.org/10.1016/j.ssresearch.2005.06.006

Buchmann, C., \& Dalton, B. (2002). Interpersonal influences and educational aspirations in 12 countries: The importance of institutional context. Sociology of Education, 99-122.

Caliendo, M., \& Kopeinig, S. (2008). Some Practical Guidance for the Implementation of Propensity Score Matching. Journal of Economic Surveys, 22(1), 31-72.

Caliendo, Marco, \& Kopeinig, S. (2008). Some Practical Guidance for the Implementation of Propensity Score Matching. Journal of Economic Surveys, 22(1), 31-72. https://doi.org/10.1111/j.1467-6419.2007.00527.x

Call, K. T., \& Mortimer, J. T. (2001). Arenas of comfort in adolescence: A study of adjustment in context. Psychology Press.

Calvo-Armengol, A., Patacchini, E., \& Zenou, Y. (2009). Peer Effects and Social Networks in Education. Review of Economic Studies, 76(4), 1239-1267.

Cammarota, J. (2004). The Gendered and Racialized Pathways of Latina and Latino Youth: Different Struggles, Different Resistances in the Urban Context. Anthropology \& Education Quarterly, 35(1), 53-74. https://doi.org/10.1525/aeq.2004.35.1.53

Carbonaro, W. J. (1998). A Little Help from My Friend's Parents: Intergenerational Closure and Educational Outcomes. Sociology of Education, 71(4), 295. https://doi.org/10.2307/2673172

Carbonaro, W., \& Workman, J. (2013). Dropping out of high school: Effects of close and distant friendships. Social Science Research, 42(5), 1254-1268. https://doi.org/10.1016/j.ssresearch.2013.05.003

Carbonaro, W., \& Workman, J. (2016). Intermediate peer contexts and educational outcomes: Do the friends of students' friends matter? Social Science Research, 58, 184-197. https://doi.org/10.1016/j.ssresearch.2016.02.005

Carrell, S. E., Fullerton, R. L., \& West, J. E. (2009). Does Your Cohort Matter? Measuring Peer Effects in College Achievement. Journal of Labor Economics, 27(3), 439-464.

Ceja, M. (2004). Chicana College Aspirations and the Role of Parents: Developing Educational Resiliency. Journal of Hispanic Higher Education, 3(4), 338-362. https://doi.org/10.1177/1538192704268428

Ceja, M. (2006). Understanding the Role of Parents and Siblings as Information Sources in the College Choice Process of Chicana Students. Journal of College Student Development, 47(1), 87104. https://doi.org/10.1353/csd.2006.0003 
Cheng, S., \& Starks, B. (2002). Racial differences in the effects of significant others on students' educational expectations. Sociology of Education, 75(4), 306-327.

Cherng, H.-Y. S., Calarco, J. M., \& Kao, G. (2012). Along for the Ride Best Friends' Resources and Adolescents' College Completion. American Educational Research Journal, 0002831212466689. https://doi.org/10.3102/0002831212466689

Choi, K. H., Kelly Raley, R., Muller, C., \& Riegle-Crumb, C. (2008). Class Composition: Socioeconomic Characteristics of Coursemates and College Enrollment*. Social Science Quarterly, 89(4), 846-866. https://doi.org/10.1111/j.1540-6237.2008.00587.x

Coleman, J. (1961). The Adolescent Society: The Social Life of the Teenager and its Impact on Education. Greenwood Press.

Coleman, J. S. (1988). Social capital in the creation of human capital. American Journal of Sociology, 94, 95-121.

Collins, P. H. (2002). Black Feminist Thought: Knowledge, Consciousness, and the Politics of Empowerment. Routledge.

Cook, T. D., Shadish, W. R., \& Wong, V. C. (2008). Three conditions under which experiments and observational studies produce comparable causal estimates: New findings from within-study comparisons. Journal of Policy Analysis and Management, 27(4), 724-750. https://doi.org/10.1002/pam.20375

Cook, T. D., Steiner, P. M., \& Pohl, S. (2009). Assessing how Bias Reduction is influenced by Covariate Choice, Unreliability and Data Analytic Mode: An Analysis of Different Kinds of Within-Study Comparisons in Different Substantive Domains. Multivariate Behavioral Research, $44,828-847$.

Crosnoe, R. (2000). Friendships in Childhood and Adolescence: The Life Course and New Directions. Social Psychology Quarterly, 63, 377-391.

Crosnoe, R., Cavanagh, S., \& Elder, G. H. (2003). Adolescent friendships as academic resources: The intersection of friendship, race, and school disadvantage. Sociological Perspectives, 46(3), 331-352.

Crosnoe, Robert, \& Muller, C. (2014). Family Socioeconomic Status, Peers, and the Path to College. Social Problems, 61(4), 602-624. https://doi.org/10.1525/sp.2014.12255

D’Agostino, R. B. (1998). Propensity Score Methods for Bias Reduction in the Comparison of a Treatment to a Non-Randomized Control Group. Statistics in Medicine, 17(19), 2265-2281.

Darity, W., Castellino, D., Tyson, K., Cobb, C., \& McMillen, B. (2001). Increasing Opportunity To Learn via Access to Rigorous Courses and Programs: One Strategy for Closing the Achievement Gap for At-Risk and Ethnic Minority Students. https:// eric.ed.gov/?id=ED459303

de Brey, C., Musu, L., McFarland, J., Wilkinson-Flicker, S., Diliberti, M., Zhang, A., Branstetter, C., \& Wang, X. (2019). Status and Trends in the Education of Racial and Ethnic Groups 2018 (NCES 2019-038). U.S. Department of Education.

Dehejia, R. (2005). Practical Propensity Score Matching: A Reply to Smith and Todd. Journal of Econometrics, 125(1-2), 355-364.

DesJardins, S. L., Ahlburg, D. A., \& McCall, B. P. (2006). An integrated model of application, admission, enrollment, and financial aid. Journal of Higher Education, 77(3), 381-+.

Desmond, M., \& Turley, R. L. (2009). The Role of Familism in Explaining the Hispanic-White College Application Gap. Social Problems, 56, 311-334.

Diamond, J. B., \& Lewis, A. E. (2015). Despite the Best Intentions: How Racial Inequality Thrives in Good Schools. Oxford University Press.

DiMaggio, P., \& Garip, F. (2012). Network Effects and Social Inequality. Annual Review of Sociology, 38(1), 93-118. https://doi.org/10.1146/annurev.soc.012809.102545 
DiPrete, T. A., \& Gangl, M. (2004). Assessing bias in the estimation of causal effects: Rosenbaum bounds on matching estimators and instrumental variables estimation with imperfect instruments. Sociological Methodology, 34(1), 271-310.

Durlauf, S. N. (2002). On The Empirics Of Social Capital*. The Economic Journal, 112(483), F459F479. https://doi.org/10.1111/1468-0297.00079

Engberg, M. E., \& Wolniak, G. C. (2009). Navigating disparate pathways to college: Examining the conditional effects of race on enrollment decisions. Teachers College Record, 111(9), 2255-2279.

Engberg, M. E., \& Wolniak, G. C. (2010). Examining the Effects of High School Contexts on Postsecondary Enrollment. Research in Higher Education, 51(2), 132-153. https://doi.org/10.1007/s11162-009-9150-y

Flashman, J. (2011). Academic Achievement and Its Impact on Friend Dynamics. Sociology of Education. http://journals.sagepub.com/doi/10.1177/0038040711417014

Flashman, J. (2014). Friend Effects and Racial Disparities in Academic Achievement. Sociological Science, 1, 260-276. https://doi.org/10.15195/v1.a17

Fletcher, J. (2013). Social Interactions and College Enrollment: Evidence from the National Education Longitudinal Study. Contemporary Economic Policy, 31(4), 762-778. https://doi.org/10.1111/j.1465-7287.2012.00335.x

Fletcher, J. M. (2011). Social identity as a determinant of college enrollment. Rationality and Society, 23(3), 267-303. https://doi.org/10.1177/1043463111404666

Fletcher, J. M. (2012). Similarity in peer college preferences: New evidence from texas. Social Science Research, 41(2), 321-330. https://doi.org/10.1016/j.ssresearch.2011.11.001

Fletcher, J. M., \& Tienda, M. (2009). High School Classmates and College Success. Sociology of Education, 82(4), 287-314. https://doi.org/10.1177/003804070908200401

Fordham, S., \& Ogbu, J. U. (1986). Black Students' School Success: Coping with the "Burden of Acting White." Urban Review, 18(3), 176-206.

Fry, R. (2011). Hispanic College Enrollment Spikes, Narrowing Gaps with Other Groups.

Fry, R., \& Taylor, P. (2013). Hispanic High School Graduates Pass Whites in Rate of College Enrollment: High School Drop-out Rate at Record Low. Pew Research Center.

Fryer, R. G., \& Torelli, P. (2010). An empirical analysis of 'acting white.' Journal of Public Economics, 94(5), 380-396.

Gamoran, A., Turley, R. N. L., Turner, A., \& Fish, R. (2012). Differences between Hispanic and non-Hispanic families in social capital and child development: First-year findings from an experimental study. Research in Social Stratification and Mobility, 30(1), 97-112.

Gerber, T. P., \& Cheung, S. Y. (2008). Horizontal stratification in postsecondary education: Forms, explanations, and implications. Annual Review of Sociology, 34, 299-318.

Germán, M., Gonzales, N. A., \& Dumka, L. (2009). Familism Values as a Protective Factor for Mexican-Origin Adolescents Exposed to Deviant Peers. The Journal of Early Adolescence, 29(1), 16-42. https://doi.org/10.1177/0272431608324475

Giordano, P. C. (2003). Relationships in adolescence. Annual Review of Sociology, 29, 257-281.

Giordano, P. C., Cernkovich, S. A., \& Demaris, A. (1993). The Family and Peer Relations of Black Adolescents. Journal of Marriage and the Family, 55(2), 277-287.

González, K. P., Stoner, C., \& Jovel, J. E. (2003). Examining the Role of Social Capital in Access to College for Latinas: Toward a College Opportunity Framework. Journal of Hispanic Higher Education, 2(2), 146-170. https://doi.org/10.1177/1538192702250620

Goyette, K. A. (2008). College for some to college for all: Social background, occupational expectations, and educational expectations over time. Social Science Research, 37(2), 461-484. https://doi.org/10.1016/j.ssresearch.2008.02.002 
Grodsky, E., \& Riegle-Crumb, C. (2010). Those Who Choose and Those Who Don't: Social Background and College Orientation. Annals of the American Academy of Political and Social Science, 627, 14-35.

Guarino, C. M., Reckase, M. D., \& Wooldridge, J. M. (2014). Can Value-Added Measures of Teacher Performance Be Trusted? Education Finance and Policy, 10(1), 117-156. https://doi.org/10.1162/EDFP_a_00153

Haller, A., \& Portes, A. (1973). Status Attainment Processes. Sociology of Education, 46, 51-91.

Hallinan, M. T., \& Williams, R. A. (1990). Students' Characteristics and the Peer-Influence Process. Sociology of Education, 63(2), 122-132.

Hancock, A.-M. (2016). Intersectionality: An Intellectual History. Oxford University Press.

Hauser, R. M., Tsai, S.-L., \& Sewell, W. H. (1983). A Model of Stratification with Response Error in Social and Psychological Variables. Sociology of Education, 56, 20-46.

Hauser, Robert M. (1970). Context and Consex: A Cautionary Tale. American Journal of Sociology, $75(4), 645$.

Heckman, J. J. (2005). The Scientific Model of Causality. Sociological Methodology, 35, 1-97. JSTOR.

Heckman, J. J., Ichimura, H., \& Todd, P. (1998). Matching As An Econometric Evaluation Estimator. The Review of Economic Studies, 65(2), 261-294. https://doi.org/10.1111/1467937X.00044

Heckman, J. J., Ichimura, H., \& Todd, P. E. (1997). Matching As An Econometric Evaluation Estimator: Evidence from Evaluating a Job Training Programme. The Review of Economic Studies, 64(4), 605-654. https://doi.org/10.2307/2971733

Hill, D. H. (2008). School Strategies and the "College-Linking" Process: Reconsidering the Effects of High Schools on College Enrollment. Sociology of Education, 81(1), 53-76. https://doi.org/10.1177/003804070808100103

Holland, N. E. (2011). The power of peers: Influences on postsecondary education planning and experiences of African American students. Urban Education, 0042085911400339.

Hout, M. (2012). Social and Economic Returns to College Education in the United States. Annual Review of Sociology, 38(1), 379-400. https://doi.org/10.1146/annurev.soc.012809.102503

Hoxby, C. M., \& Avery, C. (2012). The Missing "One-Offs": The Hidden Supply of High-Achieving, Low Income Students (Working Paper No. 18586). National Bureau of Economic Research. https://doi.org/10.3386/w18586

Hurtado, S., Inkelas, K. K., Briggs, C., \& Rhee, B.-S. (1997). Differences in College Access and Choice Among Racial/Ethnic Groups: Identifying Continuing Barriers. Research in Higher Education, 38(1), 43-75. https://doi.org/10.1023/A:1024948728792

Imbens, G. W. (2004). Nonparametric Estimation of Average Treatment Effects Under Exogeneity: A Review. Review of Economics and Statistics, 86(1), 4-29. https://doi.org/10.1162/003465304323023651

Kandel, D. (1978). Homophily, Selection, and Socioalization in Adolescent Friendships. American Journal of Sociology, 84(s), 427-436.

Kane, T. J., \& Rouse, C. E. (1995). Labor-Market Returns to Two- and Four-Year College. The American Economic Review, 85(3), 600-614.

Kane, T. J., \& Rouse, C. E. (1999). The Community College: Educating Students at the Margin between College and Work. The Journal of Economic Perspectives, 13(1), 63-84.

Kena, G., Musu-Gillette, L., Robinson, J., Wang, X., Rathbun, A., Zhang, J., Wilkinson-Flicker, S., Barmer, A., \& Velez, E. D. V. (2015). The Condition of Education 2015. NCES 2015-144. National Center for Education Statistics. http://eric.ed.gov/?id=ED556901

Klopfenstein, K. (2004). Advanced Placement: Do minorities have equal opportunity? Economics of Education Review, 23(2), 115-131. 
Kubitschek, W. N., \& Hallinan, M. T. (1998). Tracking and students' friendships. Social Psychology Quarterly, 61(1), 1-15.

Langenkamp, A. G. (2010). Academic Vulnerability and Resilience during the Transition to High School: The Role of Social Relationships and District Context. Sociology of Education, 83(1), 119. https://doi.org/10.1177/0038040709356563

Langenkamp, A. G., \& Hoyt, A. D. (2017a). The stratification of college-going Latinos' postsecondary destinations. Social Science Research, 67, 176-192. https://doi.org/10.1016/j.ssresearch.2017.05.005

Langenkamp, A. G., \& Hoyt, A. D. (2017b). Leaks in Latina/o Students' College-Going Pipeline: Consequences of Educational Expectation Attrition. Journal of Hispanic Higher Education, 1538192717749878. https://doi.org/10.1177/1538192717749878

Larson, R., \& Asmussen, L. (1991). Anger, Worry, and Hurt in Early Adolescence: An Enlarging World of Negative Emotions. In M. E. Colten \& S. Gore (Eds.), Adolescent Stress: Causes and Consequences. Transaction Publishers.

Leuven, E., \& Sianesi, B. (2003). PSMATCH2: Stata Module to Perform Full Mahalanobis and Propensity Score Matching, Common Support Graphing, and Covariate Imbalance Testing.

Lin, N. (1999). Social networks and status attainment. Annual Review of Sociology, 25, 467-487.

Lomi, A., Snijders, T. A. B., Steglich, C. E. G., \& Torlo, V. J. (2011). Why are some more peer than others? Evidence from a longitudinal study of social networks and individual academic performance. Social Science Research, 40(6), 1506-1520.

Long, M. C. (2008). College quality and early adult outcomes. Economics of Education Review, 27(5), 588-602. https://doi.org/10.1016/j.econedurev.2007.04.004

Lopez-Turley, R. (2006). When Parents Want Children to Stay Home for College. Research in Higher Education, 47(7), 823-846.

Manski, C. F. (1993). Identification of Endogenous Social Effects: The Reflection Problem. Review of Economic Studies, 60(3), 531-542.

Massey, D. S., Charles, C. Z., Lundy, G., \& Fischer, M. J. (2011). The Source of the River: The Social Origins of Freshmen at America's Selective Colleges and Universities. Princeton University Press.

McCabe, J. M. (2016). Connecting in College: How Friendship Networks Matter for Academic and Social Success. The University of Chicago Press.

McPherson, M., Smith-Lovin, L., \& Cook, J. M. (2001). Birds of a feather: Homophily in social networks. Annual Review of Sociology, 27, 415-444.

Moore, J. W. (1970). Mexican-American. Prentice Hall.

Morgan, S. L., \& Harding, D. J. (2006a). Matching estimators of causal effects-Prospects and pitfalls in theory and practice. Sociological Methods \& Research, 35(1), 3-60.

Morgan, S. L., \& Harding, D. J. (2006b). Matching Estimators of Causal Effects-Prospects and Pitfalls in Theory and Practice. Sociological Methods \& Research, 35(1), 3-60.

Morgan, Stephen L., \& Winship, C. (2014a). Counterfactuals and Causal Inference: Methods and Principles for Social Research, Second Edition. Cambridge University Press.

Morgan, Stephen L., \& Winship, C. (2014b). Counterfactuals and Causal Inference: Methods and Principles for Social Research, Second Edition. Cambridge University Press.

Mullen, A. L. (2010). Degrees of Inequality: Culture, Class and Gender in American Higher Education. The Johns Hopkins University Press.

Ndura, E., Robinson, M., \& Ochs, G. (2003). Minority Students in High School Advanced Placement Courses: Opportunity and Equity Denied. American Secondary Education, 32(1), $21-$ 38. JSTOR.

Newman, P. R., \& Newman, B. M. (1976). Early adolescence and its conflict: Group identity versus alienation. Adolescence, 11(42), 261-274. 
O'Connor, C. (1997). Dispositions Toward (Collective) Struggle and Educational Resilience in the Inner City: A Case Analysis of Six African-American High School Students. American Educational Research Journal, 34(4), 593-629. https://doi.org/10.3102/00028312034004593

O'Connor, C. (1999). Race, Class, and Gender in America: Narratives of Opportunity among LowIncome African American Youths. Sociology of Education, 72(3), 137-157. JSTOR. https://doi.org/10.2307/2673226

Otero, R., Rivas, O., \& Rivera, R. (2007). Predicting Persistence of Hispanic Students in Their 1st Year of College. Journal of Hispanic Higher Education, 6(2), 163-173. https://doi.org/10.1177/1538192706298993

Ovink, S. M. (2014). "They Always Call Me an Investment”: Gendered Familism and Latino/a College Pathways. Gender \& Society, 28(2), 265-288. https://doi.org/10.1177/0891243213508308

Ovink, S. M., \& Kalogrides, D. (2015). No place like home? Familism and Latino/a-white differences in college pathways. Social Science Research, 52, 219-235. https://doi.org/10.1016/j.ssresearch.2014.12.018

Owens, J., \& Massey, D. S. (2011). Stereotype threat and college academic performance. A latent variables approach. Social Science Research, 40(1).

Palardy, G. J. (2013). High School Socioeconomic Segregation and Student Attainment. American Educational Research Journal, 50(4), 714-754. https://doi.org/10.3102/0002831213481240

Parsons, T. (1963). On the Concept of Influence. Public Opinion Quarterly, 27(1), 37-62.

Patacchini, E., Rainone, E., \& Zenou, Y. (2011). Dynamic Aspects of Teenage Friendships and Educational Attainment (SSRN Scholarly Paper ID 1758432). Social Science Research Network. https://papers.ssrn.com/abstract $=1758432$

Paternoster, R., Brame, R., Mazerolle, P., \& Piquero, A. (1998). Using the correct statistical test for the equality of regression coefficients. Criminology, 36(4), 859-866.

Payne, D. C., \& Cornwell, B. (2007). Reconsidering Peer Influences on Delinquency: Do Less Proximate Contacts Matter? Journal of Quantitative Criminology, 23(2), 127-149. https://doi.org/10.1007/s10940-006-9022-y

Perez, P. A., \& McDonough, P. M. (2008). Understanding Latina and Latino college choice: A social capital and chain migration analysis. Journal of Hispanic Higher Education.

Perna, Laura W., Rowan-Kenyon, H. T., Thomas, S. L., Bell, A., Anderson, R., \& Li, C. (2008). The role of college counseling in shaping college opportunity: Variations across high schools. The Review of Higher Education, 31(2), 131-159.

Perna, Laura Walter, \& Titus, M. A. (2005). The Relationship between Parental Involvement as Social Capital and College Enrollment: An Examination of Racial/Ethnic Group Differences. The Journal of Higher Education, 76(5), 485-518. https://doi.org/10.1080/00221546.2005.11772296

Person, A. E., \& Rosenbaum, J. E. (2006). Chain Enrollment and College Enclaves: Benefits and Drawbacks of Latino College Students' Enrollment Decisions. New Directions for Community Colleges, 133.

Portes, A., \& Zhou, M. (1993). The New Second Generation: Segmented Assimilation and Its Variants. Annals of the American Academy of Political and Social Science, 530(November), 74-96.

Posselt, J. R., Jaquette, O., Bielby, R., \& Bastedo, M. N. (2012). Access Without Equity: Longitudinal Analyses of Institutional Stratification by Race and Ethnicity, 1972-2004. American Educational Research Journal, 49(6), 1074-1111. https://doi.org/10.3102/0002831212439456 
Ream, R. K., \& Rumberger, R. W. (2008). Student engagement, peer social capital, and school dropout among Mexican American and non-Latino white students. Sociology of Education, 81(2), 109-139.

Reynolds, J. R., \& Johnson, M. K. (2011). Change in the Stratification of Educational Expectations and Their Realization. Social Forces, 90(1), 85-109. https://doi.org/10.1093/sf/90.1.85

Reynolds, J., Stewart, M., Macdonald, R., \& Sischo, L. (2006). Have Adolescents Become Too Ambitious? High School Seniors' Educational and Occupational Plans, 1976 to 2000. Social Problems, 53(2), 186-206. https://doi.org/10.1525/sp.2006.53.2.186

Riegle-Crumb, C. (2010). More Girls Go to College: Exploring the Social and Academic Factors Behind the Female Postsecondary Advantage Among Hispanic and White Students. Research in Higher Education, 51(6), 573-593. https:/ / doi.org/10.1007/s11162-010-9169-0

Riegle-Crumb, C., Farkas, G., \& Muller, C. (2006). The Role of Gender and Friendship in Advanced Course Taking. Sociology of Education, 79(3), 206-228. https://doi.org/10.1177/003804070607900302

Rosenbaum, J. E., \& Harris, L. E. (2001). Low-Income Families in Their New Neighborhoods. Journal of Family Issues, 22(2), 183-210.

Rosenbaum, P. (2002). Observational Studies. Springer.

Rosenbaum, P., \& Rubin, D. (1983a). Assessing Sensitivity to an Unobserved Binary Covariate in an Observational Study with Binary Outcome. Journal of the Royal Statistical Society Series B, 45(2), 212-218.

Rosenbaum, P., \& Rubin, D. B. (1983b). The Central Role of the Propensity Score in Observational Studies for Causal Effects. Biometrika, 70(1), 41-55.

Rouse, C. E. (1995). Democratization or Diversion? The Effect of Community Colleges on Educational Attainment. Journal of Business \& Economic Statistics, 13(2), 217-224. https://doi.org/10.1080/07350015.1995.10524596

Rubin, D. (1974). Estimating Causal Effects of Treatments in Randomized and Nonrandomized Studies. Journal of Educational Psychology, 66, 688-701.

Rubin, D. (1980). Discussion of "Randomization Analysis of Experimental Data in the Fisher Randomization Test" by Basu. Journal of the American Statistical Association, 75, 591-593.

Rubin, D. B. (1978). Bayesian Inference for Causal Effects: The Role of Randomization. Annals of Statistics, 6(1), 34-58.

Sabogal, F., Marin, G., Oterosabogal, R., Marin, B. V., \& Perezstable, E. J. (1987). Hispanic Familism and Acculturation-What Changes and What Doesnt. Hispanic Journal of Behavioral Sciences, 9(4), 397-412.

Sacerdote, B. (2001). Peer Effects With Random Assignment: Results For Dartmouth Roommates. The Quarterly Journal of Economics, 116(2), 681-704.

Sacerdote, B. (2011). Peer Effects in Education: How Might They Work, How Big Are They and How Much Do We Know Thus Far? Handbook of the Economics of Education, 3, 249-277.

Sewell, W. H., Haller, A. O., \& Portes, A. (1969). The Educational and Early Occupational Attainment Process. American Sociological Review, 34(1), 82-92. https://doi.org/10.2307/2092789

Shadish, W. R., Clark, M. H., \& Steiner, P. M. (2008). Can Nonrandomized Experiments Yield Accurate Answers? A Randomized Experiment Comparing Random and Nonrandom Assignments. Journal of the American Statistical Association, 103(484), 1334-1343.

Shadish, W. R., Cook, T. D., \& Campbell, D. T. (2002a). Experimental and quasi-experimental designs for generalized inference. Houghton Mifflin.

Shadish, W. R., Cook, T. D., \& Campbell, D. T. (2002b). Experimental and Quasi-Experimental Designs for Generalized Inference. Houghton Mifflin. 
Sharkey, P., \& Faber, J. (2014). Where, When, Why, and for Whom Do Residential Contexts Matter? Moving Away from the Dichotomous Understanding of Neighborhood Effects. Annual Review of Sociology, 40(27), 1-27.21.

Sokatch, A. (2006). Peer influences on the college-going decisions of low socioeconomic status urban youth. Education and Urban Society, 39(1), 128-146.

Stack, C. (1974). All Our Kin. Harper \& Row.

Stanton-Salazar, R. (1997). A Social Capital Framework for Understanding the Socialization of Racial Minority Children and Youths. Harvard Educational Review, 67(1), 1-41. https://doi.org/10.17763/haer.67.1.140676g74018u73k

Stanton-Salazar, R. D. (2001). Manufacturing Hope and Despair: The School and Kin Support Networks of U.S.-Mexican Youth. Teachers College Press.

Steele, C., \& Aronson, J. (1995). Stereotype Threat and the Intellectual Test Performance of African Americans. Journal of Personality and Social Psychology, 69(5).

Stinebrickner, R., \& Stinebrickner, T. R. (2006). What can be learned about peer effects using college roommates? Evidence from new survey data and students from disadvantaged backgrounds. Journal of Public Economics, 90(8-9), 1435-1454.

Stuart, E., \& Rubin, D. B. (2008). Best Practices in Quasi-Experimental Designs: Matching Methods for Causal Inference (J. Osborne, Ed.; pp. 155-176). Sage Publications.

Sy, S. R., \& Romero, J. (2008). Family Responsibilities Among Latina College Students From Immigrant Families. Journal of Hispanic Higher Education, 7(3), 212-227. https://doi.org/10.1177/1538192708316208

Triandis, H. C., Betancourt, M. G., Lisansky, J., \& Chang, B. (1982). Dimensions of familism among Hispanic and mainstream Nayy recruits (Technical Report No. 14). Department of Psychology.

Turley, R. N. L., Desmond, M., \& Bruch, S. K. (2010). Unanticipated Educational Consequences of a Positive Parent-Child Relationship. Journal of Marriage and Family, 72(5), 1377-1390. https://doi.org/10.1111/j.1741-3737.2010.00771.x

Tyson, K. (2011). Integration Interrupted: Tracking, Black Students, and Acting White after Brown. Oxford University Press.

Tyson, K., Darity, W., \& Castellino, D. R. (2005). It's Not “A Black Thing”: Understanding the Burden of Acting White and Other Dilemmas of High Achievement. American Sociological Review, 70(4), 582-605.

Valenzuela, A., \& Dornbusch, S. M. (1994). Familism and social capital in the academic achievement of Mexican origin and Anglo adolescents. Social Science Quarterly, 75(1), 18-36.

von Hippel, P. T. (2007). Regression with Missing Y's: An Improved Strategy for Analyzing Multiply Imputed Data. Sociological Methodology, 37.

Wells, R. S., Seifert, T. A., \& Saunders, D. B. (2013). Gender and Realized Educational Expectations: The Roles of Social Origins and Significant Others. Research in Higher Education, 54(6), 599_ 626. https://doi.org/10.1007/s11162-013-9308-5

Woelfel, J., \& Haller, A. O. (1971). Significant others, the self-reflexive act and the attitude formation process. American Sociological Review, 74-87.

Wolniak, G. C., \& Engberg, M. E. (2010). Academic Achievement in the First Year of College: Evidence of the Pervasive Effects of the High School Context. Research in Higher Education, 51(5), 451-467. https://doi.org/10.1007/s11162-010-9165-4

Wooldridge, J. M. (2005). Violating Ignorability of Treatment by Controlling for Too Many Factors. Econometric Theory, 21(5), 1026-1028. https://doi.org/10.1017/S0266466605050516

Zhang, L. (2005). Advance to Graduate Education: The Effect of College Quality and Undergraduate Majors. The Review of Higher Education, 28(3), 313-338. https://doi.org/10.1353/rhe.2005.0030 
Zimmerman, D. J. (2003). Peer Effects in Academic Oucomes: Evidence from a Natural Experiment. The Review of Economics and Statistics, 85(1), 9-23. 


\section{Propensity score matching balance tests}

\section{Standardized percent bias across observed covariates}
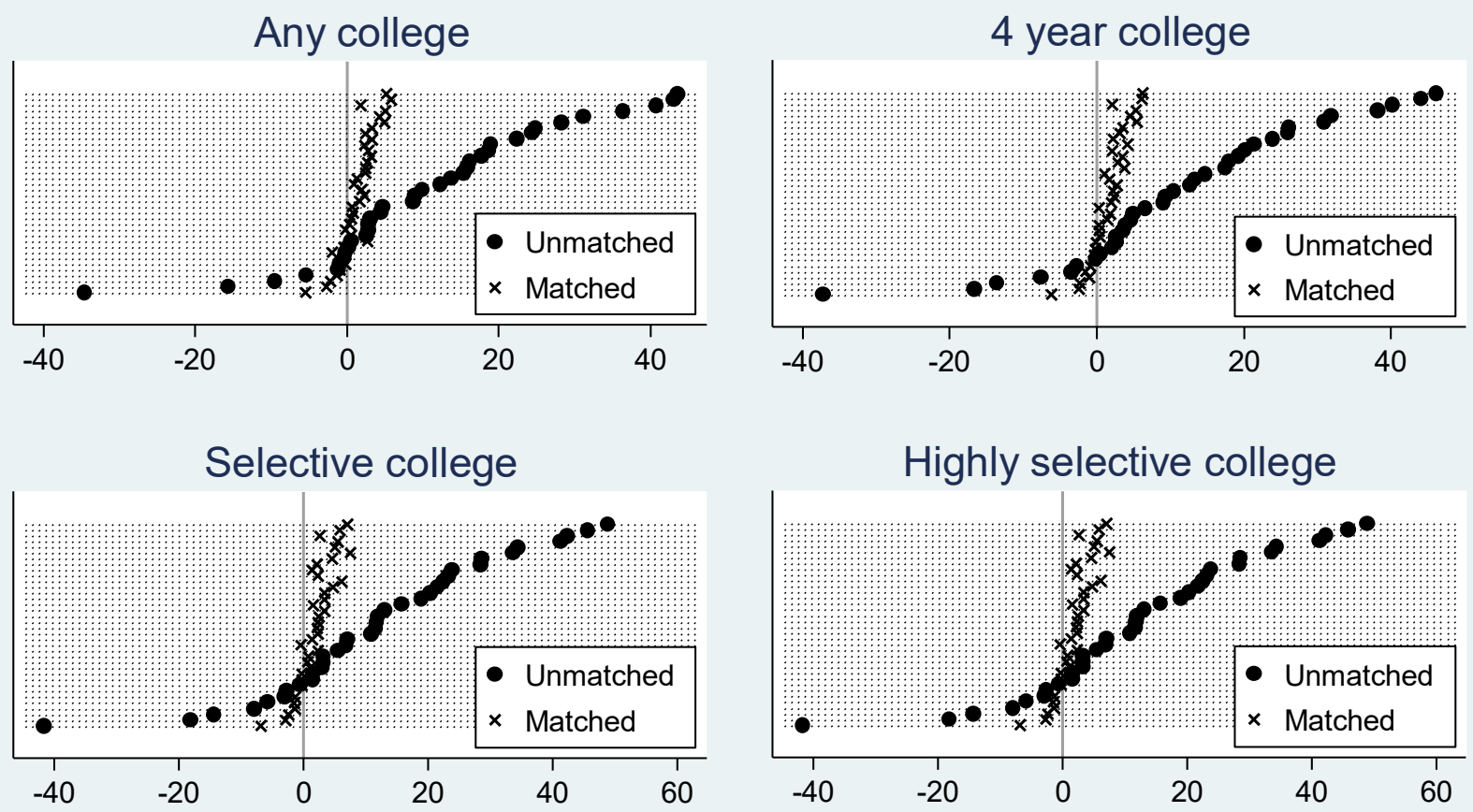

Vertical line is perfect balance. Results are for all students combined

Source: U.S. Department of Education, High School Longitudinal Study (2009 - 2013)

Figure 1. Bias in observed covariates before and after matching on propensity scores for all students. 


\begin{tabular}{|c|c|c|c|c|c|c|c|c|}
\hline \multirow[b]{2}{*}{ Variable } & \multicolumn{2}{|c|}{ Whites $(\mathrm{N}=14,580)$} & \multicolumn{2}{|c|}{ Asians $(\mathrm{N}=2,470)$} & \multicolumn{2}{|c|}{ Blacks $(\mathrm{N}=3,140)$} & \multicolumn{2}{|c|}{ Latinos $(\mathrm{N}=4,750)$} \\
\hline & Mean & Std. Dev. & Mean & Std. Dev. & Mean & Std. Dev. & Mean & Std. Dev. \\
\hline \multicolumn{9}{|l|}{ Treatment } \\
\hline College bound friends & 0.62 & 0.48 & 0.72 & 0.45 & 0.61 & 0.49 & 0.57 & 0.50 \\
\hline \multicolumn{9}{|l|}{ Outcomes } \\
\hline Enrolled in any college & 0.75 & 0.04 & 0.80 & 0.40 & 0.68 & 0.05 & 0.68 & 0.46 \\
\hline Enrolled in a 4 year college & 0.70 & 0.46 & 0.77 & 0.42 & 0.65 & 0.48 & 0.62 & 0.49 \\
\hline Enrolled in a selecive 4 year college & 0.81 & 0.40 & 0.85 & 0.36 & 0.69 & 0.46 & 0.73 & 0.45 \\
\hline Enrolled in a highly selecive 4 year college & 0.35 & 0.48 & 0.48 & 0.50 & 0.27 & 0.44 & 0.30 & 0.46 \\
\hline \multicolumn{9}{|l|}{ Students characteristics } \\
\hline Favorite subject is science, math, or computer science & 0.27 & 0.44 & 0.33 & 0.47 & 0.28 & 0.45 & 0.26 & 0.44 \\
\hline Advanced science course in 8 th grade & 0.05 & 0.22 & 0.07 & 0.25 & 0.06 & 0.24 & 0.06 & 0.23 \\
\hline A or B in most advanced science course in 8 th grade & 0.80 & 0.40 & 0.84 & 0.37 & 0.69 & 0.46 & 0.69 & 0.46 \\
\hline Advanced math course in 8 th grade & 0.76 & 0.42 & 0.82 & 0.39 & 0.74 & 0.44 & 0.71 & 0.45 \\
\hline A or B in most advanced math course in 8 th grade & 0.76 & 0.43 & 0.83 & 0.37 & 0.67 & 0.47 & 0.69 & 0.46 \\
\hline Educational/career plan in fall of 9 th grade & 0.60 & 0.49 & 0.67 & 0.47 & 0.71 & 0.46 & 0.62 & 0.49 \\
\hline Student took science fall of 9 th grade & 0.85 & 0.36 & 0.85 & 0.36 & 0.80 & 0.40 & 0.80 & 0.40 \\
\hline Student took math fall of 9th grade & 0.91 & 0.28 & 0.91 & 0.29 & 0.88 & 0.33 & 0.88 & 0.33 \\
\hline Math score in fall of 9 th grade & 51.78 & 9.68 & 55.76 & 10.99 & 47.85 & 9.65 & 48.99 & 9.62 \\
\hline Math score in spring of 11 th grade & 52.08 & 9.99 & 56.33 & 10.93 & 48.25 & 9.43 & 49.67 & 9.57 \\
\hline Expect to go to college in spring of 11 th grade & 0.99 & 0.11 & 0.99 & 0.09 & 0.99 & 0.12 & 0.98 & 0.13 \\
\hline $\begin{array}{l}\text { Overall high school grade point average, honors- } \\
\text { weighted }\end{array}$ & 2.92 & 0.92 & 3.20 & 0.91 & 2.49 & 0.94 & 2.60 & 0.94 \\
\hline On academic track in high school & 0.39 & 0.49 & 0.50 & 0.50 & 0.30 & 0.46 & 0.30 & 0.46 \\
\hline $\begin{array}{l}\text { Received any financial aid (e.g., Stafford loan, work- } \\
\text { study, Pell grant, other) }\end{array}$ & 0.80 & 0.40 & 0.79 & 0.41 & 0.84 & 0.37 & 0.81 & 0.40 \\
\hline Met with a high school counselor about college & & & & & & & & \\
\hline admission in 2012-2013 & 0.77 & 0.42 & 0.82 & 0.39 & 0.81 & 0.39 & 0.77 & 0.42 \\
\hline ACT composite score & 21.66 & 4.92 & 22.47 & 5.40 & 20.52 & 4.92 & 20.82 & 4.85 \\
\hline SAT composite score & 1011.71 & 199.27 & 1046.57 & 220.84 & 963.75 & 203.97 & 981.45 & 202.69 \\
\hline \multicolumn{9}{|l|}{ Family background } \\
\hline \multicolumn{9}{|l|}{ Family income } \\
\hline $0-34 \mathrm{k}$ & 0.22 & 0.41 & 0.25 & 0.43 & 0.38 & 0.49 & 0.39 & 0.49 \\
\hline $35-74 \mathrm{k}$ & 0.32 & 0.47 & 0.31 & 0.46 & 0.31 & 0.46 & 0.30 & 0.46 \\
\hline $75-114 k$ & 0.22 & 0.41 & 0.20 & 0.40 & 0.17 & 0.37 & 0.16 & 0.37 \\
\hline $115-194 \mathrm{k}$ & 0.16 & 0.36 & 0.15 & 0.36 & 0.10 & 0.30 & 0.10 & 0.30 \\
\hline $195+\mathrm{k}$ & 0.08 & 0.28 & 0.09 & 0.29 & 0.05 & 0.22 & 0.05 & 0.22 \\
\hline In poverty & 0.17 & 0.37 & 0.21 & 0.41 & 0.30 & 0.46 & 0.32 & 0.47 \\
\hline \multicolumn{9}{|l|}{ Parents' education } \\
\hline Less than High School & 0.03 & 0.18 & 0.06 & 0.23 & 0.05 & 0.22 & 0.16 & 0.36 \\
\hline HS & 0.35 & 0.48 & 0.27 & 0.45 & 0.40 & 0.49 & 0.37 & 0.48 \\
\hline Some college & 0.42 & 0.49 & 0.39 & 0.49 & 0.38 & 0.49 & 0.34 & 0.47 \\
\hline $\mathrm{BA}+$ & 0.20 & 0.40 & 0.28 & 0.45 & 0.17 & 0.37 & 0.13 & 0.34 \\
\hline \multicolumn{9}{|l|}{ Parents' educational expectations for child } \\
\hline Less than High School & 0.00 & 0.07 & 0.00 & 0.04 & 0.00 & 0.06 & 0.00 & 0.07 \\
\hline HS & 0.09 & 0.28 & 0.05 & 0.22 & 0.10 & 0.30 & 0.09 & 0.29 \\
\hline Some college & 0.46 & 0.50 & 0.37 & 0.48 & 0.39 & 0.49 & 0.41 & 0.49 \\
\hline $\mathrm{BA}+$ & 0.45 & 0.50 & 0.57 & 0.49 & 0.51 & 0.50 & 0.49 & 0.50 \\
\hline Number of household members & 4.32 & 1.31 & 4.42 & 1.37 & 4.28 & 1.47 & 4.52 & 1.43 \\
\hline At least one parent's highest degree was STEM & 0.14 & 0.35 & 0.25 & 0.43 & 0.11 & 0.32 & 0.10 & 0.31 \\
\hline
\end{tabular}




\begin{tabular}{|c|c|c|c|c|c|c|c|c|}
\hline \multicolumn{9}{|l|}{ High s chool characteristics } \\
\hline Percent of students receiving reduced/free lunch & 29.78 & 22.71 & 28.96 & 24.78 & 40.12 & 28.01 & 40.19 & 28.03 \\
\hline $\begin{array}{l}\text { Percent of students enrolled in Advanced Placement } \\
\text { courses }\end{array}$ & 15.94 & 13.37 & 20.14 & 14.92 & 15.93 & 13.18 & 16.79 & 13.73 \\
\hline Number of full-time certified math teachers & 9.01 & 6.07 & 12.23 & 7.15 & 10.12 & 6.82 & 11.04 & 7.50 \\
\hline Number of full-time certified science teachers & 8.23 & 5.58 & 11.38 & 6.87 & 8.97 & 5.95 & 9.91 & 6.79 \\
\hline School offers advanced STEM courses & 0.78 & 0.42 & 0.79 & 0.41 & 0.71 & 0.45 & 0.78 & 0.42 \\
\hline School requires specific math courses & 0.90 & 0.29 & 0.91 & 0.29 & 0.93 & 0.26 & 0.91 & 0.28 \\
\hline School requires specific science courses & 0.87 & 0.34 & 0.87 & 0.34 & 0.88 & 0.32 & 0.86 & 0.35 \\
\hline School has a pro STEM climate & 2.87 & 1.40 & 3.48 & 1.35 & 3.01 & 1.41 & 3.12 & 1.41 \\
\hline School uses a tracking policy & 0.46 & 0.50 & 0.46 & 0.50 & 0.46 & 0.50 & 0.48 & 0.50 \\
\hline
\end{tabular}

Source: U.S. Department of Education. National Center for Educational Statistics: HSLS 2009 - 2013 
Table 2. Treatment effects of college bound friends on college enrollment outcomes stratified by race and ethnicity from propensity score matching models (bandwidth $=0.09$ )

\begin{tabular}{|c|c|c|c|c|}
\hline & Any college & Four year college & Selective & Highly selective \\
\hline \multicolumn{5}{|l|}{ All students } \\
\hline $\mathrm{CBF}$ & 0.06 & 0.10 & 0.03 & 0.07 \\
\hline Standard Error & 0.01 & 0.01 & 0.01 & 0.01 \\
\hline T-statistic & 9.13 & 11.49 & 3.23 & 7.21 \\
\hline On support untreated & 9,480 & 6,160 & 3,600 & 3,600 \\
\hline On support treated & 15,370 & 12,090 & 8,990 & 8,990 \\
\hline Off support & 70 & 60 & 130 & 130 \\
\hline Mean bias pre-matching & 14.97 & 16.27 & 17.64 & 17.63 \\
\hline Mean bias post-matching & 2.24 & 2.40 & 2.81 & 2.81 \\
\hline \multicolumn{5}{|l|}{ Whites } \\
\hline $\mathrm{CBF}$ & 0.07 & 0.10 & 0.04 & 0.07 \\
\hline Standard Error & 0.01 & 0.01 & 0.01 & 0.01 \\
\hline T-statistic & 7.51 & 9.20 & 3.47 & 5.43 \\
\hline On support untreated & 5,530 & 3,580 & 2,090 & 2,090 \\
\hline On support treated & 9,030 & 7,330 & 5,530 & 5,530 \\
\hline Off support & 80 & 40 & 50 & 50 \\
\hline Mean bias pre-matching & 17.83 & 17.65 & 18.66 & 18.66 \\
\hline Mean bias post-matching & 2.26 & 2.55 & 2.79 & 2.79 \\
\hline \multicolumn{5}{|l|}{ Asians } \\
\hline $\mathrm{CBF}$ & 0.08 & 0.07 & 0.03 & 0.08 \\
\hline Standard Error & 0.02 & 0.03 & 0.03 & 0.04 \\
\hline T-statistic & 3.43 & 2.34 & 1.00 & 2.11 \\
\hline On support untreated & 730 & 500 & 340 & 340 \\
\hline On support treated & 1,680 & 1,430 & 1,160 & 1,160 \\
\hline Off support & 20 & 70 & 50 & 50 \\
\hline Mean bias pre-matching & 19.81 & 21.76 & 22.25 & 22.25 \\
\hline Mean bias post-matching & 3.32 & 4.24 & 4.29 & 4.30 \\
\hline
\end{tabular}


Blacks

\begin{tabular}{|c|c|c|c|c|}
\hline $\mathrm{CBF}$ & 0.04 & 0.08 & -0.03 & 0.05 \\
\hline Standard Error & 0.02 & 0.02 & 0.03 & 0.03 \\
\hline T-statistic & 2.18 & 3.30 & -0.93 & 1.93 \\
\hline On support untreated & 1,200 & 767 & 150 & 450 \\
\hline On support treated & 1,940 & 1,344 & 930 & 930 \\
\hline Off support & 30 & 10 & 10 & 10 \\
\hline Mean bias pre-matching & 10.13 & 12.26 & 14.72 & 14.71 \\
\hline Mean bias post-matching & 2.22 & 2.19 & 2.44 & 2.45 \\
\hline \multicolumn{5}{|l|}{ Latinos } \\
\hline $\mathrm{CBF}$ & 0.03 & 0.12 & 0.02 & 0.03 \\
\hline Standard Error & 0.01 & 0.02 & 0.02 & 0.02 \\
\hline T-statistic & 1.74 & 6.33 & 1.04 & 1.42 \\
\hline On support untreated & 2,030 & 1,310 & 720 & 720 \\
\hline On support treated & 2,720 & 1,928 & 1,300 & 1,300 \\
\hline Off support & 40 & 30 & 20 & 20 \\
\hline Mean bias pre-matching & 11.59 & 13.17 & 15.87 & 15.87 \\
\hline Mean bias post-matching & 1.77 & 1.79 & 2.21 & 2.21 \\
\hline
\end{tabular}

All models include full set of covariate adjustments

Bold ATTs denote statistically significant effects $(\mathrm{p}<0.05)$.

Source: U.S. Department of Education. National Center for Educational Statistics: HSLS 2009 - 2013 
Table 3. Sensitivity analysis: Magnitude of the unobserved binary confounder's effect on selection into the treatment that renders the ATT null $(\mathrm{p}<0.05)$.

\begin{tabular}{ccccc}
\hline \hline & $(1)$ & $(2)$ & $(3)$ & $(4)$ \\
& Any college & 4 year college & Selective & Highly selective \\
\cline { 2 - 5 } All & \multicolumn{5}{c}{$\Gamma$ (odds ratios) } \\
students & $1.85-1.90$ & $>2.0$ & $1.40-1.45$ & $1.50-1.55$ \\
Whites & $>2.0$ & $>2.0$ & $1.50-1.55$ & $1.45-1.50$ \\
Asians & $>2.0$ & $1.90-1.95$ & - & $1.95-2.00$ \\
Blacks & $1.15-1.20$ & $1.45-1.50$ & - & - \\
Latinos & - & $1.75-1.80$ & - & - \\
\hline Mantel-Haenszel bounds for treatment effects of college bound friend on high \\
Binary unobserved confounder effect on selection into the treatment $(\Gamma)$ is in the \\
metric of odds ratios in increments of 0.05 between 1.00 and 2.00. \\
Source: U.S. Department of Education. National Center for Educational \\
Statistics: HSLS 2009-13.
\end{tabular}


Table 4. Treatment effects of college bound friends (11th grade) on college enrollment outcomes stratified by race and ethnicity from propensity score matching models (bandwidth $=0.03$ ).

\begin{tabular}{|c|c|c|c|c|}
\hline & Any college & Four year college & Selective & Highly selective \\
\hline \multicolumn{5}{|l|}{ All students } \\
\hline $\mathrm{CBF}$ & 0.05 & 0.09 & 0.02 & 0.05 \\
\hline Standard Error & 0.01 & 0.01 & 0.01 & 0.01 \\
\hline T-statistic & 7.34 & 9.14 & 2.24 & 4.53 \\
\hline On support untreated & 9,478 & 6,157 & 3,596 & 3,596 \\
\hline On support treated & 15,371 & 12,085 & 8,991 & 8,991 \\
\hline Off support & 70 & 60 & 130 & 130 \\
\hline Mean bias pre-matching & 14.97 & 16.27 & 17.63 & 17.64 \\
\hline Mean bias post-matching & 1.10 & 1.16 & 1.23 & 1.23 \\
\hline \multicolumn{5}{|l|}{ Whites } \\
\hline $\mathrm{CBF}$ & 0.06 & 0.09 & 0.04 & 0.05 \\
\hline Standard Error & 0.01 & 0.01 & 0.01 & 0.01 \\
\hline T-statistic & 6.09 & 7.29 & 2.75 & 3.62 \\
\hline On support untreated & 5,527 & 3,584 & 2,091 & 2,091 \\
\hline On support treated & 9,028 & 7,330 & 5,528 & 5,528 \\
\hline Off support & 80 & 40 & 50 & 50 \\
\hline Mean bias pre-matching & 17.84 & 17.64 & 18.66 & 18.66 \\
\hline Mean bias post-matching & 1.42 & 1.68 & 1.63 & 1.63 \\
\hline \multicolumn{5}{|l|}{ Asians } \\
\hline $\mathrm{CBF}$ & 0.08 & 0.06 & 0.02 & 0.03 \\
\hline Standard Error & 0.03 & 0.03 & 0.04 & 0.04 \\
\hline T-statistic & 3.11 & 1.86 & 0.55 & 0.72 \\
\hline On support untreated & 727 & 496 & 336 & 336 \\
\hline On support treated & 1,677 & 1,431 & 1,155 & 1,155 \\
\hline Off support & 20 & 70 & 50 & 50 \\
\hline Mean bias pre-matching & 19.81 & 21.76 & 22.24 & 22.25 \\
\hline Mean bias post-matching & 2.59 & 3.17 & 3.64 & 3.64 \\
\hline
\end{tabular}


Blacks

CBF

0.03

0.07

$-0.03$

0.05

Standard Error

0.02

0.02

0.03

0.03

T-statistic

1.82

2.92

$-1.15$

1.69

On support untreated

1,197

767

449

449

On support treated

1,935

1,344

931

931

Off support

30

Mean bias pre-matching

10.13

10

10

10

Mean bias post-matching

1.42

12.26

14.72

14.72

1.51

2.08

2.08

\section{Latinos}

$\mathrm{CBF}$

0.02

Standard Error

0.02

T-statistic

1.06

On support untreated

2,027

2,721

On support treated

40

Off support

Mean bias pre-matching

11.59

0.94

0.11

0.02

0.02

0.02

0.02

0.02

5.43

0.66

0.87

Mean bias post-matching

1,310

720

720

1,928

1,296

1,296

20

20

All models include full set of covariate adjustments

Bold ATTs denote statistically significant effects $(\mathrm{p}<0.05)$.

Source: U.S. Department of Education. National Center for Educational Statistics: HSLS 2009 - 2013 


\begin{tabular}{|c|c|c|c|c|}
\hline & Any college & Four year college & Selective & Highly selective \\
\hline \multicolumn{5}{|l|}{ All students } \\
\hline $\mathrm{CBF}$ & 0.04 & 0.08 & 0.01 & 0.06 \\
\hline Standard Error & 0.06 & 0.01 & 0.01 & 0.01 \\
\hline T-statistic & 5.71 & 10.02 & 1.80 & 5.77 \\
\hline On support untreated & 19,271 & 13,720 & 9,027 & 9,027 \\
\hline On support treated & 5,656 & 4,567 & 3,595 & 3,595 \\
\hline Off support & 0 & 0 & & \\
\hline Mean bias pre-matching & 12.56 & 13.02 & 13.21 & 13.21 \\
\hline Mean bias post-matching & 1.72 & 1.59 & 1.48 & 1.48 \\
\hline \multicolumn{5}{|l|}{ Whites } \\
\hline $\mathrm{CBF}$ & 0.03 & 0.08 & 0.02 & 0.06 \\
\hline Standard Error & 0.01 & 0.01 & 0.01 & 0.01 \\
\hline T-statistic & 3.35 & 7.65 & 1.73 & 4.80 \\
\hline On support untreated & 11,371 & 8,283 & 5,527 & 5,527 \\
\hline On support treated & 3,203 & 2,649 & 2,122 & 2,122 \\
\hline Off support & 0 & 0 & 0 & 0 \\
\hline Mean bias pre-matching & 14.53 & 14.43 & 14.87 & 14.87 \\
\hline Mean bias post-matching & 1.69 & 1.50 & 1.35 & 1.35 \\
\hline \multicolumn{5}{|l|}{ Asians } \\
\hline $\mathrm{CBF}$ & 0.04 & 0.04 & 0.01 & 0.06 \\
\hline Standard Error & 0.02 & 0.21 & 0.02 & 0.03 \\
\hline T-statistic & 2.08 & 2.14 & 0.34 & 2.11 \\
\hline On support untreated & 1,748 & 1,334 & 997 & 997 \\
\hline On support treated & 716 & 625 & 522 & 522 \\
\hline Off support & 0 & 0 & 0 & 0 \\
\hline Mean bias pre-matching & 17.39 & 17.16 & 17.37 & 17.37 \\
\hline Mean bias post-matching & 1.71 & 1.37 & 1.57 & 1.57 \\
\hline
\end{tabular}




\section{Blacks}

$\mathrm{CBF}$

0.04

0.10

$-0.01$

0.01

Standard Error

0.02

2.17

0.02

0.03

0.03

T-statistic

2,356

4.44

$-0.33$

0.26

On support untreated

1,567

974

On support treated

777

Off support

0

Mean bias pre-matching

8.87

Mean bias post-matching

1.88

570

974

435

0

435

0

$\begin{array}{lll}10.14 & 9.34 & 9.34\end{array}$

1.72

1.44

1.44

Latinos

CBF

$\mathbf{0 . 0 5}$

0.09

0.03

0.03

Standard Error

0.02

0.02

0.02

0.02

T-statistic

3.36

4.29

1.09

1.27

On support untreated

3,796

2,536

1,529

1,529

On support treated

951

715

510

510

Off support

10

0

0

Mean bias pre-matching

9.69

10.64

0

12.44

Mean bias post-matching

2.11

1.78

12.44

1.52

All models include full set of covariate adjustments

Bold ATTs denote statistically significant effects $(\mathrm{p}<0.05)$.

Source: U.S. Department of Education. National Center for Educational Statistics: HSLS 2009 - 2013 


\section{Appendix A: Sensitivity analysis}

The sensitivity analyses allow me to gauge the strength of my estimates in the face of bias introduced through a hypothetical single unobserved binary variable, $U$, that impacts selection into treatment, net of the observed covariates (P. Rosenbaum, 2002; P. Rosenbaum \& Rubin, 1983a). Rosenbaum (2002) argued that by generating a hypothetical unobserved variable and manipulating its effect on selection into the treatment, researchers can place bounds ('Rosenbaum bounds') for significance levels and confidence intervals around the treatment effect and assess how strong the unmeasured variable must be before the treatment effect is undermined (DiPrete \& Gangl, 2004). I used an extension of Rosenbaum bounds, called Mantel-Haenszel bounds, that is specifically created to address unobserved heterogeneity (i.e., 'hidden bias') when using binary outcomes.

The sensitivity analysis incrementally manipulates the odds ratio of selection into the treatment, gamma $(\Gamma)$, until the original ATT is no longer statistically significant. That is, I continue to increase the odds of selection into the treatment attributed to $U$ until I 'kill' the observed ATT from the propensity score model, which I evaluate by examining the corresponding $\mathrm{p}$-value $\left(\mathrm{p} \_\mathrm{mh}+\right)$ associated with each increase in $\Gamma$. The increments for $\Gamma$ are in the metric of odds ratios and are 0.05 in size, ranging between 1.00 and 2.00. This method allows me to pinpoint which specific failure (within 0.05 increments) of the ignorability assumption implied by the particular configuration of the parameter, $\Gamma$, renders my results statistically insignificant. I can then compare the strength of association at the 'kill' point of $U$ to a conceptually important observed variable. Importantly, however, one must keep in mind that the sensitivity analysis provides levels of strength for an unobserved confounder that must be added to the model net of the observed covariates. Comparing the strength of the unobserved confounder with observed covariates will facilitate a clearer understanding of the type of unobserved confounder that must added to the model to 
undermine my results. This exercise says nothing about the realistic plausibility of such a theoretical confounder actually existing, however. 
Appendix B. Logistic regression results for the unadjusted moderating effect of race and ethnicity on the associations between CBF and college enrollment outcomes stratified by gender.

\begin{tabular}{|c|c|c|c|c|c|c|c|c|}
\hline \multirow[b]{3}{*}{ All students } & \multicolumn{2}{|c|}{ Any college } & \multicolumn{2}{|c|}{4 year college } & \multicolumn{2}{|c|}{$\underline{\text { Selective }}$} & \multicolumn{2}{|c|}{ Highly selective } \\
\hline & Coefficient & Standard Error & Coefficient & Standard Error & Coefficient & Standard Error & Coefficient & Standard Error \\
\hline & & & & & & & & \\
\hline \multicolumn{9}{|l|}{ Main effects } \\
\hline $\mathrm{CBF}$ & 0.85 & 0.04 & 0.85 & 0.04 & 0.62 & 0.06 & 0.57 & 0.06 \\
\hline Asian & 0.12 & 0.09 & 0.35 & 0.1 & 0.08 & 0.14 & 0.28 & 0.13 \\
\hline Black & -0.06 & 0.07 & -0.07 & 0.08 & -0.25 & 0.11 & -0.10 & 0.12 \\
\hline Latino & -0.11 & 0.05 & -0.12 & 0.07 & -0.25 & 0.1 & 0.00 & 0.10 \\
\hline \multicolumn{9}{|c|}{ Interaction effects } \\
\hline $\mathrm{CBF}^{*}$ Asian & 0.07 & 0.11 & -0.09 & 0.12 & 0.25 & 0.17 & 0.38 & 0.15 \\
\hline $\mathrm{CBF} *$ Black & -0.49 & 0.09 & -0.28 & 0.1 & -0.59 & 0.14 & -0.35 & 0.14 \\
\hline $\mathrm{CBF} *$ Latino & -0.38 & 0.07 & -0.31 & 0.09 & -0.31 & 0.12 & -0.32 & 0.12 \\
\hline Constant & 0.61 & 0.03 & 0.29 & 0.03 & 1.03 & 0.05 & -1.05 & 0.05 \\
\hline Observations & 24,930 & & 18290 & & 12600 & & 12,600 & \\
\hline \multicolumn{9}{|l|}{ Females } \\
\hline \multicolumn{9}{|l|}{ Main effects } \\
\hline $\mathrm{CBF}$ & 0.91 & 0.06 & 0.81 & 0.06 & 0.66 & 0.09 & 0.58 & 0.08 \\
\hline Asian & 0.09 & 0.13 & 0.38 & 0.15 & 0.03 & 0.2 & 0.15 & 0.19 \\
\hline Black & -0.19 & 0.1 & -0.25 & 0.11 & -0.32 & 0.16 & -0.23 & 0.18 \\
\hline Latino & -0.24 & 0.08 & -0.22 & 0.09 & -0.51 & 0.14 & -0.09 & 0.15 \\
\hline \multicolumn{9}{|c|}{ Interaction effects } \\
\hline $\mathrm{CBF}^{*}$ Asian & -0.001 & 0.16 & -0.18 & 0.18 & 0.22 & 0.24 & 0.55 & 0.21 \\
\hline CBF * Black & -0.4 & 0.13 & -0.12 & 0.14 & -0.62 & 0.2 & -0.23 & 0.21 \\
\hline $\mathrm{CBF} *$ Latino & -0.32 & 0.11 & -0.15 & 0.12 & -0.19 & 0.17 & -0.28 & 0.17 \\
\hline Constant & 0.79 & 0.04 & 0.34 & 0.05 & 1.06 & 0.07 & -1.07 & 0.07 \\
\hline Observations & 12,190 & & 9,350 & & 6500 & & 6,500 & \\
\hline \multicolumn{9}{|l|}{ Males } \\
\hline \multicolumn{9}{|l|}{ Main effects } \\
\hline $\mathrm{CBF}$ & 0.79 & 0.05 & 0.88 & 0.06 & 0.56 & 0.08 & 0.56 & 0.08 \\
\hline Asian & 0.14 & 0.11 & 0.32 & 0.14 & 0.13 & 0.2 & 0.40 & 0.18 \\
\hline Black & 0.04 & 0.09 & 0.11 & 0.11 & -0.18 & 0.16 & 0.01 & 0.16 \\
\hline Latino & -0.0001 & 0.07 & -0.03 & 0.09 & -0.02 & 0.13 & 0.06 & 0.13 \\
\hline \multicolumn{9}{|c|}{ Interaction effects } \\
\hline $\mathrm{CBF} *$ Asian & 0.14 & 0.15 & 0.003 & 0.17 & 0.28 & 0.24 & 0.22 & 0.20 \\
\hline CBF * Black & -0.54 & 0.12 & -0.43 & 0.14 & -0.54 & 0.19 & -0.44 & 0.19 \\
\hline $\mathrm{CBF} *$ Latino & -0.42 & 0.1 & -0.47 & 0.12 & -0.4 & 0.17 & -0.35 & 0.16 \\
\hline Constant & 0.47 & 0.04 & 0.23 & 0.04 & 1 & 0.07 & -1.03 & 0.07 \\
\hline Observations & 12,740 & & 8,940 & & 6102 & & 6,100 & \\
\hline
\end{tabular}

Source: U.S. Department of Education. National Center for Educational Statistics: HSLS 2009 - 2013

Coefficients in bold denote statistically significant associations $(\mathrm{p}<0.05)$ 
Appendix C. Treatment effects of college bound friends (11th grade) on college enrollment stratified by race and ethnicity from propensity score matching models (bandwidth $=0.09$ ): Females.

\begin{tabular}{|c|c|c|c|c|}
\hline & Any college & Four year college & Selective & Highly selective \\
\hline \multicolumn{5}{|l|}{ Whites } \\
\hline $\mathrm{CBF}$ & 0.06 & 0.09 & 0.08 & 0.10 \\
\hline Standard Error & 0.01 & 0.02 & 0.02 & 0.02 \\
\hline T-statistic & 4.61 & 5.65 & 4.22 & 5.35 \\
\hline On support untreated & 2,553 & 1,758 & 1,007 & 1,007 \\
\hline On support treated & 4,482 & 3,812 & 2,924 & 2,924 \\
\hline Off support & 70 & 40 & 40 & 40 \\
\hline Mean bias pre-matching & 18.37 & 18.08 & 18.56 & 18.56 \\
\hline Mean bias post-matching & 2.31 & 2.67 & 3.31 & 3.31 \\
\hline \multicolumn{5}{|l|}{ Asians } \\
\hline $\mathrm{CBF}$ & 0.10 & 0.01 & 0.09 & 0.20 \\
\hline Standard Error & 0.03 & 0.04 & 0.05 & 0.05 \\
\hline T-statistic & 3.00 & 0.32 & 1.99 & 3.94 \\
\hline On support untreated & 336 & 238 & 151 & 151 \\
\hline On support treated & 874 & 670 & 573 & 573 \\
\hline Off support & 25 & 100 & 50 & 50 \\
\hline Mean bias pre-matching & 18.79 & 20.74 & 20.71 & 20.71 \\
\hline Mean bias post-matching & 4.72 & 3.87 & 6.46 & 6.46 \\
\hline \multicolumn{5}{|l|}{ Blacks } \\
\hline $\mathrm{CBF}$ & 0.09 & 0.06 & -0.02 & 0.06 \\
\hline Standard Error & 0.03 & 0.04 & 0.05 & 0.04 \\
\hline T-statistic & 3.20 & 1.74 & -0.51 & 1.61 \\
\hline On support untreated & 593 & 383 & 220 & 220 \\
\hline On support treated & 902 & 651 & 417 & 417 \\
\hline Off support & 10 & 30 & 50 & 50 \\
\hline Mean bias pre-matching & 12.30 & 13.83 & 17.75 & 17.75 \\
\hline Mean bias post-matching & 2.64 & 2.96 & 3.53 & 3.53 \\
\hline \multicolumn{5}{|l|}{ Latinos } \\
\hline $\mathrm{CBF}$ & 0.09 & 0.11 & 0.07 & 0.03 \\
\hline Standard Error & 0.02 & 0.03 & 0.04 & 0.03 \\
\hline T-statistic & 4.22 & 3.95 & 1.98 & 1.00 \\
\hline On support untreated & 955 & 606 & 323 & 323 \\
\hline On support treated & 1,390 & 1,036 & 735 & 735 \\
\hline Off support & 5 & 20 & 10 & 10 \\
\hline Mean bias pre-matching & 11.85 & 13.61 & 15.61 & 15.61 \\
\hline Mean bias post-matching & 2.09 & 2.26 & 3.01 & 3.01 \\
\hline
\end{tabular}

All models include full set of covariate adjustments

Bold ATTs denote statistically significant effects $(\mathrm{p}<0.05)$.

Source: U.S. Department of Education. National Center for Educational Statistics: HSLS 2009 - 2013 
Appendix D. Treatment effects of college bound friends (11th grade) on college enrollment stratified by race and ethnicity from propensity score matching models (bandwidth $=0.09$ ): Males.

\begin{tabular}{|c|c|c|c|c|}
\hline & Any college & Four year college & Selective & Highly selective \\
\hline \multicolumn{5}{|l|}{ Whites } \\
\hline $\mathrm{CBF}$ & 0.07 & 0.12 & 0.06 & 0.04 \\
\hline Standard Error & 0.01 & 0.02 & 0.02 & 0.02 \\
\hline T-statistic & 5.65 & 7.30 & 2.96 & 2.40 \\
\hline On support untreated & 3,000 & 1,846 & 1,071 & 1,071 \\
\hline On support treated & 4,377 & 3,417 & 2,522 & 2,522 \\
\hline Off support & 40 & 20 & 50 & 50 \\
\hline Mean bias pre-matching & 17.86 & 17.65 & 19.27 & 19.27 \\
\hline Mean bias post-matching & 2.30 & 2.65 & 2.79 & 2.79 \\
\hline \multicolumn{5}{|l|}{ Asians } \\
\hline $\mathrm{CBF}$ & 0.11 & 0.10 & 0.11 & 0.08 \\
\hline Standard Error & 0.03 & 0.04 & 0.06 & 0.05 \\
\hline T-statistic & 3.25 & 2.35 & 1.86 & 1.65 \\
\hline On support untreated & 373 & 241 & 156 & 156 \\
\hline On support treated & 855 & 711 & 555 & 555 \\
\hline Off support & 20 & 10 & 30 & 30 \\
\hline Mean bias pre-matching & 17.95 & 18.30 & 20.07 & 20.07 \\
\hline Mean bias post-matching & 4.20 & 4.93 & 6.77 & 6.77 \\
\hline \multicolumn{5}{|l|}{ Blacks } \\
\hline $\mathrm{CBF}$ & 0.02 & 0.06 & 0.05 & -0.06 \\
\hline Standard Error & 0.03 & 0.03 & 0.04 & 0.04 \\
\hline T-statistic & 0.95 & 1.65 & 1.15 & -1.39 \\
\hline On support untreated & 638 & 399 & 242 & 242 \\
\hline On support treated & 995 & 677 & 481 & 481 \\
\hline Off support & 10 & 10 & 10 & 10 \\
\hline Mean bias pre-matching & 10.94 & 13.20 & 15.64 & 15.64 \\
\hline Mean bias post-matching & 2.16 & 2.71 & 3.23 & 3.23 \\
\hline \multicolumn{5}{|l|}{ Latinos } \\
\hline $\mathrm{CBF}$ & 0.03 & 0.10 & 0.06 & 0.01 \\
\hline Standard Error & 0.02 & 0.03 & 0.03 & 0.03 \\
\hline T-statistic & 1.56 & 2.21 & 1.66 & 0.42 \\
\hline On support untreated & 1,084 & 667 & 378 & 378 \\
\hline On support treated & 1,340 & 919 & 596 & 596 \\
\hline Off support & 10 & 20 & 20 & 20 \\
\hline Mean bias pre-matching & 12.31 & 13.96 & 17.68 & 17.68 \\
\hline Mean bias post-matching & 1.92 & 2.09 & 2.68 & 2.68 \\
\hline
\end{tabular}

All models include full set of covariate adjustments

Bold ATTs denote statistically significant effects $(\mathrm{p}<0.05)$.

Source: U.S. Department of Education. National Center for Educational Statistics: HSLS 2009 - 2013 


\section{Appendix E: Results from Sensitivity Analysis}

In Model 1, the results demonstrate that unobserved confounder, $U$, undermines the statistically significant ATT for the effect of CBF on enrolling in any college among all students when $U$ is between 1.85 and 1.90 , net of controls. That is, the ATT is no longer statistically significant when $U$ caused the odds ratio of treatment assignment to differ between treatment and control cases by a factor of about 1.90 for all students after including observed covariates in the model. Furthermore, the results demonstrate that $U$ undermines the statistically significant ATT for the effect of $\mathrm{CBF}$ on enrolling in any college among White and Asian students when $U$ is somewhere above 2.0 , beyond the 2.0 limit of the sensitivity analysis. That is, the effect of $U$ on selection into the treatment must be 'off the charts' in order to undermine the AT'Ts for White and Asian students. Lastly, the results demonstrate that $U$ undermines the ATT for Black students when $U$ caused the odds ratio of treatment assignment to differ between treatment and control cases by a factor of about 1.20 for all students after including observed covariates in the model. The ATT for Black students, therefore, represents the weakest ATT in this paper, yet still not necessarily overly worrisome.

In Model 2, the critical level of $\Gamma$ at which I would have to question my conclusion of a positive effect of $\mathrm{CBF}$ on enrolling in a 4 year college among all students combined and among White students is once again above 2.0, net of observed covariates. Among Asian students, a hidden bias of between 1.90 and 1.95 would be necessary to render the results of a positive effect of CBF spurious, net of observed covariates. The hidden bias must be between 1.45 and 1.50 for Black students and between 1.75 and 1.80 for Latino students to undermine the effect of CBF on 4 year college enrollment.

In Model 3, I would have to question my conclusion of a positive effect of CBF on enrolling in a selective college if the critical level of $\Gamma$ were approximately 1.45 among all students and 
approximately 1.55 among White students, net of observed covariates. Finally, in Model 4, the treatment effects for enrolling in a highly selective college would effectively be undermined by an unobserved confounder if the critical level of $\Gamma$ were approximately 1.55 among all students, 1.50 among White students, and 2.0 among Asian students.

Converting the results of Table 3 from odds ratios to coefficients and comparing the results for the bounds of the 'killer' confounder in Model 1 (any college) of Table 3 with the selection effects of observed covariates in Appendix F, an unobserved confounder would have to be about 6 times stronger than $8^{\text {th }}$ grade math achievement $(\ln (1.90)=0.64 ; 0.64 / 0.10=6.4)$, approximately 9 times stronger than family income $(0.64 / 0.07=9.14)$, and 4 times stronger than GPA $(0.64 / 0.13=$ 4.92) to render the result for all students spurious. Among White and Asian students, the killer confounder would have a corresponding coefficient of 0.69 in terms of its effect on selection into the treatment to render my results null. This corresponds to selection effects on the treatment that are once again much larger than any of the observed covariates' impact on selection; which include achievement, family income, and GPA. Among Black students, the killer confounder's selection effect (0.18) would have to be approximately as large as that of being in poverty (0.19) to undermine the treatment effect of $\mathrm{CBF}$ on enrolling in any college. It is important to recall, however, that this theoretical confounder would have to be similar or larger in size than any of these observed covariates after already including the covariates in the model as controls, which I have done. The results for enrolling in any college appear to be most robust for White and Asian students.

Examining the sensitivity results in Model 2 in Table 3, the unobserved confounder would have to be five and four times as strong as GPA $(0.13 \& 0.15)$ to render the ATTs on enrolling in a 4 year college among all students and White students null, respectively. Among Asian, Black, and Latino students, the killer confounder would have to be four times stronger than GPA (0.21), twice as strong as poverty, and almost six times as strong as family income to render the ATTs for 
enrollment in a 4 year college null, respectively. The results for enrolling in a 4 year college appear to be most robust for White students.

Examining Model 3 of Table 3, the killer confounder would have to be 2.8 times as strong as GPA (0.13) or about as strong as being in an academic track (0.38) to undermine the ATT for enrollment in a selective college among all students. Among White students, the killer confounder would have to be approximately 3 times as strong as GPA (0.15) and slightly stronger than being in an academic track (0.38) to undermine the ATT for enrolling in a selective college.

Finally, examining the results from Model 4 of Table 3, the unobserved killer confounder would have to be approximately 3 times as strong as GPA $(0.13 \& 0.15)$ and slightly stronger than being in an academic track $(0.38 \& 0.38)$ to undermine the ATT for enrollment in a highly selective college among all students and among White students, respectively. Among Asian students, the killer confounder would have to be more than 3 times stronger than $8^{\text {th }}$ grade math achievement $(0.20)$ or GPA (0.21) to render my ATT for enrollment in a highly selective college null. The results for enrollment in a highly selective college appear most robust for Asian students. 


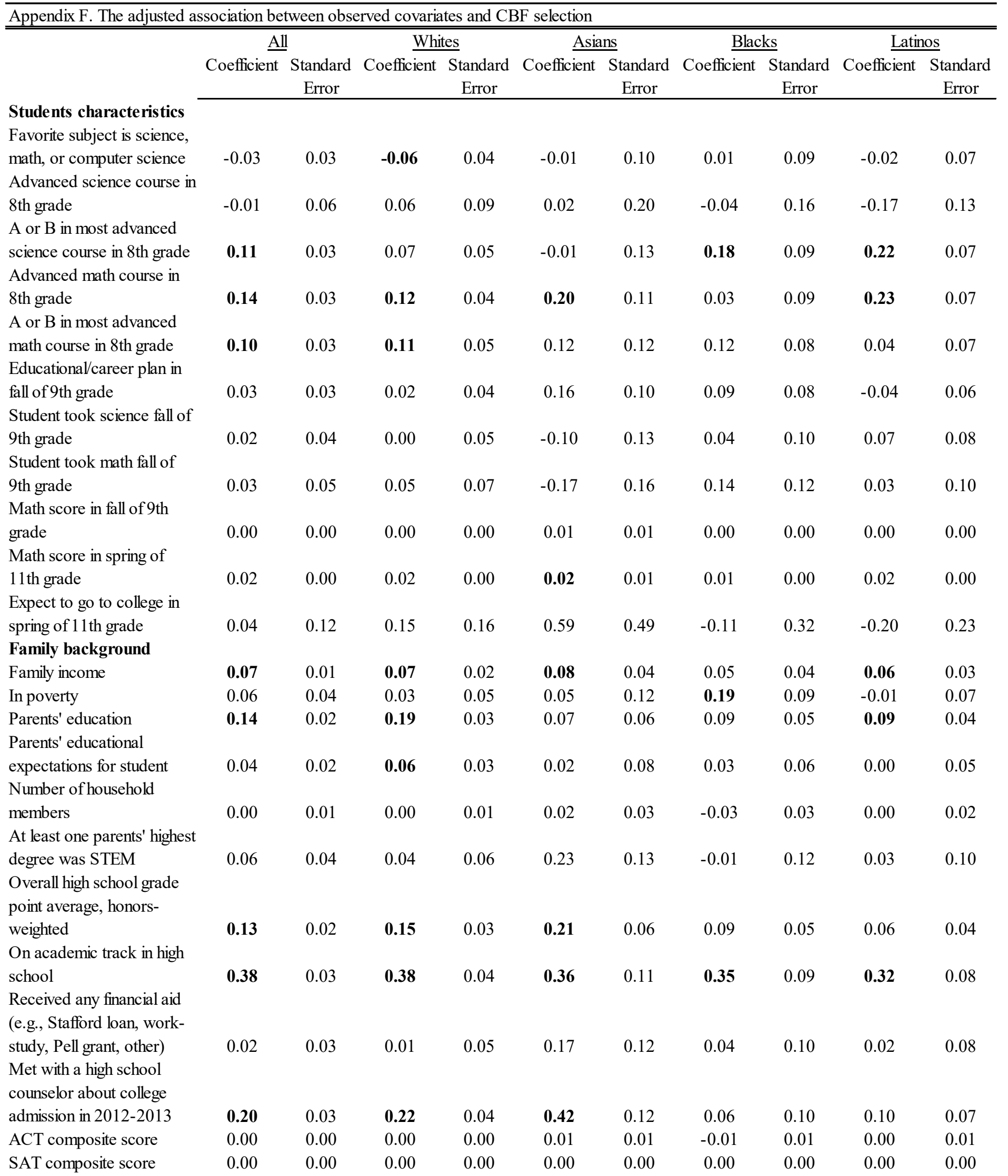




\begin{tabular}{|c|c|c|c|c|c|c|c|c|c|c|}
\hline \multicolumn{11}{|c|}{ Appendix F (continued). The adjusted association between observed covariates and CBF selection } \\
\hline & \multicolumn{2}{|c|}{$\underline{\text { All }}$} & \multicolumn{2}{|c|}{ Whites } & \multicolumn{2}{|c|}{$\underline{\text { Asians }}$} & \multicolumn{2}{|c|}{$\underline{\text { Blacks }}$} & \multicolumn{2}{|c|}{$\underline{\text { Latinos }}$} \\
\hline & Coefficient & $\begin{array}{l}\text { Standard } \\
\text { Error }\end{array}$ & Coefficient & $\begin{array}{l}\text { Standard } \\
\text { Error }\end{array}$ & Coefficient & $\begin{array}{l}\text { Standard } \\
\text { Error }\end{array}$ & Coefficient & $\begin{array}{l}\text { Standard } \\
\text { Error }\end{array}$ & Coefficient & $\begin{array}{c}\text { Standard } \\
\text { Error }\end{array}$ \\
\hline $\begin{array}{l}\text { High school } \\
\text { characteristics }\end{array}$ & & & & & & & & & & \\
\hline $\begin{array}{l}\text { Percent of students } \\
\text { receiving reduced/free lunch } \\
\text { Percent of students enrolled } \\
\text { in Advanced Placement }\end{array}$ & -0.01 & 0.00 & -0.01 & 0.00 & -0.01 & 0.00 & -0.01 & 0.00 & -0.01 & 0.00 \\
\hline courses & 0.00 & 0.00 & 0.01 & 0.00 & 0.01 & 0.00 & 0.00 & 0.00 & 0.01 & 0.00 \\
\hline $\begin{array}{l}\text { Number of full-time } \\
\text { certified math teachers }\end{array}$ & 0.00 & 0.00 & 0.00 & 0.01 & 0.00 & 0.01 & -0.01 & 0.01 & 0.01 & 0.01 \\
\hline $\begin{array}{l}\text { Number of full-time } \\
\text { certified science teachers }\end{array}$ & 0.00 & 0.00 & 0.00 & 0.01 & 0.00 & 0.01 & 0.00 & 0.01 & -0.01 & 0.01 \\
\hline $\begin{array}{l}\text { School offers advanced } \\
\text { STEM courses }\end{array}$ & 0.05 & 0.03 & 0.06 & 0.04 & -0.15 & 0.12 & 0.21 & 0.09 & 0.02 & 0.07 \\
\hline $\begin{array}{l}\text { School requires specific } \\
\text { math courses }\end{array}$ & 0.03 & 0.05 & 0.05 & 0.07 & 0.14 & 0.19 & -0.02 & 0.16 & -0.02 & 0.12 \\
\hline $\begin{array}{l}\text { School requires specific } \\
\text { science courses }\end{array}$ & 0.01 & 0.05 & 0.01 & 0.06 & -0.09 & 0.16 & -0.09 & 0.13 & 0.11 & 0.10 \\
\hline $\begin{array}{l}\text { School has a pro STEM } \\
\text { climate }\end{array}$ & 0.03 & 0.01 & 0.02 & 0.02 & 0.08 & 0.05 & 0.04 & 0.03 & 0.04 & 0.03 \\
\hline $\begin{array}{l}\text { School uses a tracking } \\
\text { policy }\end{array}$ & -0.04 & 0.03 & -0.06 & 0.04 & -0.19 & 0.10 & 0.09 & 0.08 & 0.00 & 0.06 \\
\hline Constant & -2.48 & & -2.95 & & -3.41 & & -1.20 & & -1.40 & \\
\hline Observations & 24,930 & & 14,580 & & 2,470 & & 3,140 & & 4,750 & \\
\hline
\end{tabular}

Source: U.S. Department of Education. National Center for Educational Statistics: HSLS 2009 - 2013

Coefficients in bold denote statistically significant associations $(\mathrm{p}<0.05)$ 
Appendix G. School fixed effects analysis of the impact of college bound friends on college enrollment outcomes: (1) Homogeneous effects across race and ethnicity and (2) Multiplicative effects (CBF*race/ethnicity)

\begin{tabular}{|c|c|c|c|c|}
\hline & Any college & $\begin{array}{c}\text { Four year } \\
\text { college }\end{array}$ & $\begin{array}{c}\text { Selective } \\
\text { college }\end{array}$ & $\begin{array}{c}\text { Highly selective } \\
\text { college }\end{array}$ \\
\hline \multicolumn{5}{|c|}{ (1) Homogeneous effects } \\
\hline \multicolumn{5}{|c|}{ All students } \\
\hline \multirow[t]{2}{*}{$\mathrm{CBF}$} & 0.29 & 0.30 & 0.11 & 0.08 \\
\hline & $(0.01)$ & $(0.01)$ & $(0.02)$ & $(0.02)$ \\
\hline \multicolumn{5}{|c|}{ (2) Interaction model } \\
\hline \multicolumn{5}{|c|}{ Main effects } \\
\hline \multirow[t]{2}{*}{$\mathrm{CBF}$} & 0.40 & $\mathbf{0 . 3 7}$ & 0.17 & 0.04 \\
\hline & $(0.01)$ & $(0.02)$ & $(0.02)$ & $(0.02)$ \\
\hline \multirow[t]{2}{*}{ Asian } & -0.10 & 0.31 & 0.09 & 0.05 \\
\hline & $(0.03)$ & $(0.04)$ & $(0.05)$ & $(0.05)$ \\
\hline \multirow[t]{2}{*}{ Black } & 0.03 & 0.26 & -0.02 & -0.16 \\
\hline & $(0.02)$ & $(0.03)$ & $(0.04)$ & $(0.04)$ \\
\hline \multirow[t]{2}{*}{ Latino } & 0.06 & 0.07 & 0.03 & 0.06 \\
\hline & $(0.02)$ & $(0.02)$ & $(0.04)$ & $(0.04)$ \\
\hline \multicolumn{5}{|c|}{ Interaction effects } \\
\hline \multirow[t]{2}{*}{$\mathrm{CBF}^{*}$ Asian } & 0.07 & -0.20 & -0.03 & 0.25 \\
\hline & $(0.04)$ & $(0.04)$ & $(0.06)$ & $(0.05)$ \\
\hline \multirow[t]{2}{*}{ CBF*Black } & -0.26 & -0.21 & -0.30 & 0.07 \\
\hline & $(0.03)$ & $(0.04)$ & $(0.05)$ & $(0.05)$ \\
\hline \multirow[t]{2}{*}{ CBF*Latino } & -0.31 & -0.14 & -0.07 & -0.01 \\
\hline & $(0.03)$ & $(0.03)$ & $(0.04)$ & $(0.04)$ \\
\hline
\end{tabular}

Beta coefficients and robust standard errors

All models adjust for all family background and student control variables

Bold coefficients denote statistical significance $(\mathrm{p}<0.05)$.

Source: U.S. Department of Education. National Center for Educational Statistics: HSLS 2009 - 2013 


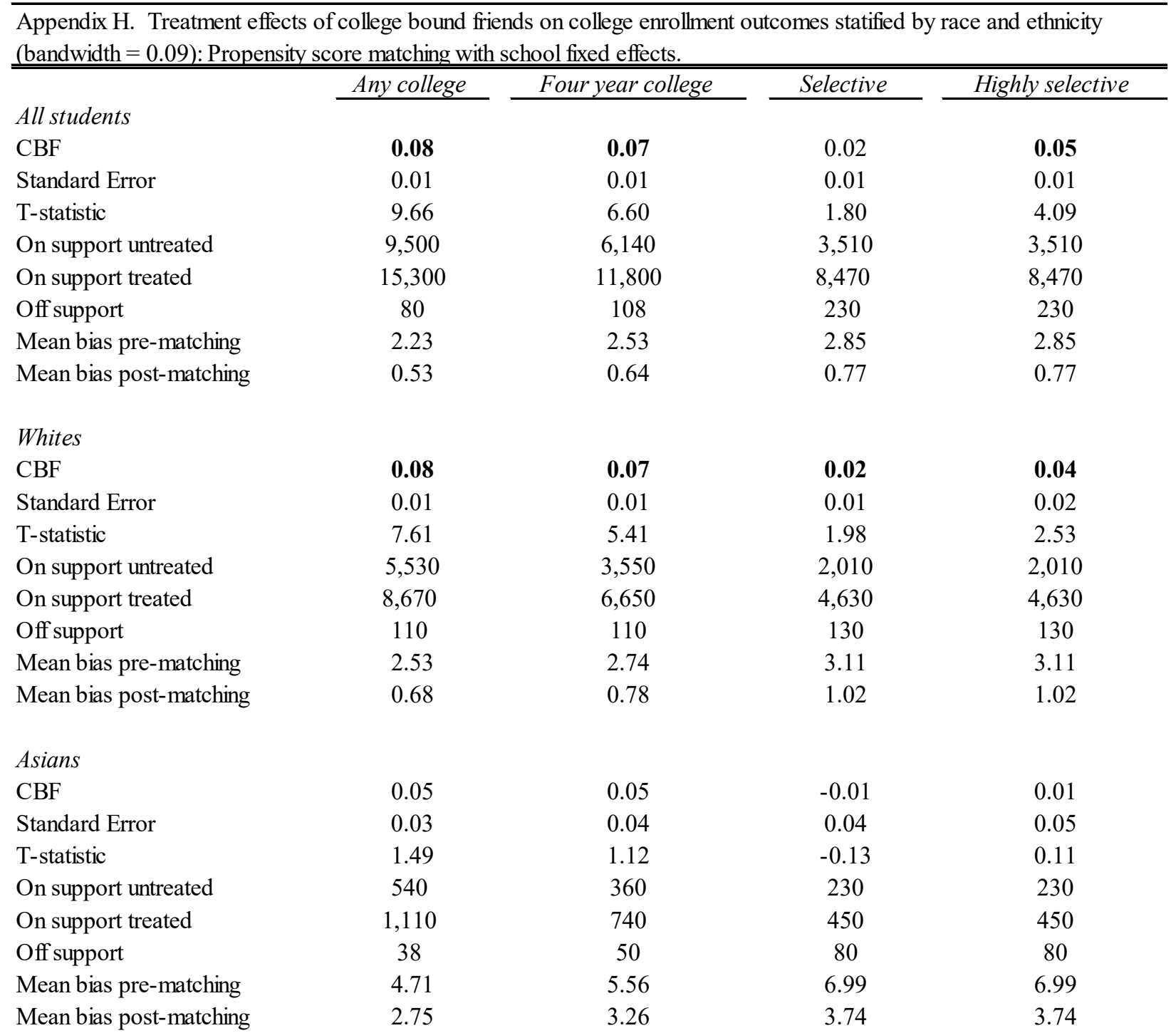




$\begin{array}{lcccc}\text { Blacks } & & & & \\ \text { CBF } & \mathbf{0 . 0 5} & 0.01 & 0.01 & \mathbf{0 . 0 8} \\ \text { Standard Error } & 0.02 & 0.03 & 0.04 & 0.04 \\ \text { T-statistic } & 2.19 & 0.42 & 0.30 & 2.05 \\ \text { On support untreated } & 1,030 & 590 & 310 & 310 \\ \text { On support treated } & 1,380 & 810 & 460 & 460 \\ \text { Off support } & 10 & 40 & 40 & 40 \\ \text { Mean bias pre-matching } & 2.92 & 3.73 & 4.98 & 4.98 \\ \text { Mean bias post-matching } & 1.11 & 1.64 & 2.85 & \\ & & & & \\ \text { Latinos } & & & 0.03 & 0.03 \\ \text { CBF } & 0.02 & \mathbf{0 . 0 7} & 0.03 & 0.03 \\ \text { Standard Error } & 0.02 & 0.02 & 0.99 & 540 \\ \text { T-statistic } & 1.33 & 2.87 & 540 & 740 \\ \text { On support untreated } & 1,900 & 1,140 & 740 & 10 \\ \text { On support treated } & 2,240 & 1,410 & 10 & 4.04 \\ \text { Off support } & 10 & 10 & 4.04 & 1.62 \\ \text { Mean bias pre-matching } & 2.58 & 3.26 & 1.62 & \\ \text { Mean bias post-matching } & 0.82 & 1.08 & \end{array}$

All models include full set of covariate adjustments

Bold ATTs denote statistically significant effects $(\mathrm{p}<0.05)$.

Source: U.S. Department of Education. National Center for Educational Statistics: HSLS 2009 - 2013 


\begin{tabular}{|c|c|c|c|c|c|c|c|c|c|c|c|c|c|c|c|c|c|c|c|c|}
\hline & \multicolumn{5}{|c|}{ Any college } & \multicolumn{5}{|c|}{ Four year college } & \multicolumn{5}{|c|}{ Selective college } & \multicolumn{5}{|c|}{ Highly selective college } \\
\hline & (1) & (2) & (3) & (4) & (5) & (6) & (7) & (8) & (9) & (10) & (11) & (12) & $(13)$ & (14) & (15) & (16) & (17) & (18) & (19) & (20) \\
\hline & All & Whites & Asians & Blacks & Latinos & All & Whites & Asians & Blacks & Latinos & All & Whites & Asians & Blacks & Latinos & All & Whites & Asians & Blacks & Latinos \\
\hline $\mathrm{CBF}$ & $\begin{array}{c}0.056^{* * * *} \\
(0.0056)\end{array}$ & $\begin{array}{l}0.066^{* * *} \\
(0.0071)\end{array}$ & $\begin{array}{c}0.063 * * * \\
(0.018)\end{array}$ & $\begin{array}{l}0.040^{*} \\
(0.017)\end{array}$ & $\begin{array}{l}0.024+ \\
(0.013)\end{array}$ & $\begin{array}{r}0.078^{* * *} \\
(0.0071)\end{array}$ & $\begin{array}{r}* 0.091 * * * \\
(0.0091)\end{array}$ & $\begin{array}{c}0.013 \\
(0.022)\end{array}$ & $\begin{array}{c}0.033 \\
(0.021)\end{array}$ & $\begin{array}{c}0.089 * * * \\
(0.017)\end{array}$ & $\begin{array}{c}0.021^{*} \\
(0.0082)\end{array}$ & $\begin{array}{c}0.031 * * \\
(0.010)\end{array}$ & $\begin{array}{l}0.0033 \\
(0.023)\end{array}$ & $\begin{array}{l}-0.019 \\
(0.027)\end{array}$ & $\begin{array}{c}0.028 \\
(0.021)\end{array}$ & $\begin{array}{c}0.022 * \\
(0.0094)\end{array}$ & $\begin{array}{c}0.013 \\
(0.012)\end{array}$ & $\begin{array}{c}0.032 \\
(0.030)\end{array}$ & $\begin{array}{l}0.056^{*} \\
(0.026)\end{array}$ & $\begin{array}{c}0.017 \\
(0.022)\end{array}$ \\
\hline Constant & $\begin{array}{l}0.064+ \\
(0.037)\end{array}$ & $\begin{array}{c}0.022 \\
(0.046)\end{array}$ & $\begin{array}{c}-0.042 \\
(0.11)\end{array}$ & $\begin{array}{c}0.16 \\
(0.12)\end{array}$ & $\begin{array}{l}0.27^{* *} \\
(0.090)\end{array}$ & $\begin{array}{c}-0.31 * * * \\
(0.046)\end{array}$ & $\begin{array}{c}-0.32 * * * \\
(0.060)\end{array}$ & $\begin{array}{l}-0.14 \\
(0.13)\end{array}$ & $\begin{array}{c}-0.68^{* * *} \\
(0.15)\end{array}$ & $\begin{array}{l}-0.18 \\
(0.12)\end{array}$ & $\begin{array}{c}0.20^{* * *} \\
(0.053)\end{array}$ & $\begin{array}{c}0.26^{* * *} \\
(0.066)\end{array}$ & $\begin{array}{l}0.28^{*} \\
(0.14)\end{array}$ & $\begin{array}{l}0.39^{*} \\
(0.20)\end{array}$ & $\begin{array}{c}-0.066 \\
(0.14)\end{array}$ & $\begin{array}{c}-0.62 * * * \\
(0.060)\end{array}$ & $\begin{array}{c}-0.59^{* * * *} \\
(0.078)\end{array}$ & $\begin{array}{c}-1.00^{* * * *} \\
(0.19)\end{array}$ & $\begin{array}{c}-0.36+ \\
(0.19)\end{array}$ & $\begin{array}{c}-0.49^{* * *} \\
(0.15)\end{array}$ \\
\hline $\mathrm{N}$ & 24930 & 14560 & 2490 & 3150 & 4730 & 18290 & 10910 & 1970 & 2160 & 3250 & 12620 & 7630 & 1530 & 1420 & 2030 & 12620 & 7630 & 1530 & 1420 & 2030 \\
\hline
\end{tabular}

Standard errors in parentheses

All models include full adjustments for observed characteristics

Source: U.S. Department of Education. National Center for Educational Statistics: HSLS 2009 - 2013

$+\mathrm{p}<.10 * \mathrm{p}<0.05 * * \mathrm{p}<0.01 * * * \mathrm{p}<0.001$ 
Appendix J. OLS full-factorial interaction regression results for the moderating effect of race and ethnicity on the association between $\mathrm{CBF}$ and college enrollment outcomes for all students.

Any college Four year college Selective college Highly selective college

(1)

All students

\section{Main effects}

\begin{tabular}{|c|c|c|c|c|}
\hline $\mathrm{CBF}$ & $\begin{array}{c}0.075 * * * \\
(0.0072)\end{array}$ & $\begin{array}{c}0.093 * * * \\
(0.0090)\end{array}$ & $\begin{array}{c}0.033 * * \\
(0.010)\end{array}$ & $\begin{array}{c}0.019 \\
(0.012)\end{array}$ \\
\hline Asian & $\begin{array}{r}-0.0085 \\
(0.017)\end{array}$ & $\begin{array}{c}0.082 * * * \\
(0.021)\end{array}$ & $\begin{array}{c}0.035 \\
(0.024)\end{array}$ & $\begin{array}{c}0.021 \\
(0.027)\end{array}$ \\
\hline Black & $\begin{array}{c}0.022+ \\
(0.013)\end{array}$ & $\begin{array}{c}0.061 * * * \\
(0.017)\end{array}$ & $\begin{array}{l}-0.019 \\
(0.021)\end{array}$ & $\begin{array}{l}-0.018 \\
(0.024)\end{array}$ \\
\hline Latino & $\begin{array}{c}0.032 * * \\
(0.011)\end{array}$ & $\begin{array}{c}0.010 \\
(0.014)\end{array}$ & $\begin{array}{c}-0.031+ \\
(0.018)\end{array}$ & $\begin{array}{c}0.026 \\
(0.020)\end{array}$ \\
\hline \multicolumn{5}{|c|}{ Interaction effects } \\
\hline $\mathrm{CBF}^{*}$ Asian & $\begin{array}{l}-0.012 \\
(0.020)\end{array}$ & $\begin{array}{c}-0.084 * * * \\
(0.024)\end{array}$ & $\begin{array}{l}-0.032 \\
(0.027)\end{array}$ & $\begin{array}{c}0.052+ \\
(0.031)\end{array}$ \\
\hline CBF $*$ Black & $\begin{array}{c}-0.043 * * \\
(0.017)\end{array}$ & $\begin{array}{c}-0.052 * \\
(0.021)\end{array}$ & $\begin{array}{c}-0.054^{*} \\
(0.025)\end{array}$ & $\begin{array}{c}0.012 \\
(0.028)\end{array}$ \\
\hline CBF * Latino & $\begin{array}{c}-0.059 * * * \\
(0.014)\end{array}$ & $\begin{array}{l}-0.011 \\
(0.018)\end{array}$ & $\begin{array}{l}-0.012 \\
(0.021)\end{array}$ & $\begin{array}{l}-0.021 \\
(0.024)\end{array}$ \\
\hline Constant & $\begin{array}{c}0.056 \\
(0.037)\end{array}$ & $\begin{array}{c}-0.32 * * * \\
(0.047)\end{array}$ & $\begin{array}{c}0.22 * * * \\
(0.053)\end{array}$ & $\begin{array}{c}-0.60 * * * \\
(0.061)\end{array}$ \\
\hline Observations & 24930 & 18290 & 12620 & 12620 \\
\hline
\end{tabular}

Standard errors in parentheses

All models include full adjustments for observed characteristics

Source: U.S. Department of Education. National Center for Educational Statistics: HSLS 2009 - 2013

$+\mathrm{p}<0.1 * \mathrm{p}<0.05 * * \mathrm{p}<0.01 * * * \mathrm{p}<0.001$ 


\section{Endnotes:}

${ }^{1}$ Data is only available to account for post-secondary enrollment in the semester immediately following ontime high school graduation.

${ }^{2}$ However, the influence of friendship may be limited. The "arena of comfort" (Giordano, 2003) that friendship provides may prevent influence as much as it facilitates it because of the recycling of norms and values. That is, new potential friends may introduce exciting new ideas that could outweigh more established norms within a friendship circle and exert (more) influence than actual friends (Giordano, 2003). Structural arrangements within the school may moderate the influence of friends. For instance, tracking may influence how students respond to high-achieving friends if students feel angst and pressure regarding their position in the academic hierarchy (Tyson, 2011).

${ }^{3}$ The influence of older friends who have already matriculated into college may also influence students' decisions to apply to and enroll in college through a process of educational 'chain migration.' Person and Rosenbaum (2006) analyzed patterns of enrollment for older students in respondents' social network and found that for Latino students, these older students were important for accessing important information about college. Also, Perez and McDonough (2008) found that access to exposure to a greater range of college choice options was made possible by access to strong social networks among Latino students. Furthermore, Ceja (2006) found that when parents were unable to provide information about the college choice process, older siblings who had experience were often able to provide assistance.

${ }^{4}$ Moreover, qualitative, observational, and quasi-experimental studies have found that high-achieving peers can also boost grade point averages once students are in college (Alemán \& M, 2000; Carrell et al., 2009; J. M. Fletcher \& Tienda, 2009; McCabe, 2016; Sacerdote, 2001; Stinebrickner \& Stinebrickner, 2006; Zimmerman, 2003).

${ }^{5}$ Robust observational (Choi et al., 2008; R. Crosnoe, 2000; Flashman, 2014) and experimental (Sacerdote, 2001; Zimmerman, 2003) estimates of peer effects suggest independent effects for actors nested within one's educational environment. For instance, previous research has found that high-achieving school and classroom-level peers have positive impacts on cognitive and achievement outcomes (Ding and Lehrer, 2007; Hanushek, 2003; Henry and Rickman, 2007; Lefgren, 2004; Lin, 2010; Neidell and Waldfogel, 2010). Crosnoe and Muller (2014) found that peers with college-educated parents positively impacted advanced course work in high school. Also, 12th grade classmates (Fletcher, 2012) and the proportion of high school classmates who go to college (Engberg and Wolniak, 2010; Fletcher, 2013) may increase college attendance. Similarly, Bifulco and colleagues $(2011,2014)$ found that students' exposure to high school classmates with college educated mothers increased college attendance. Babcock (2008) found that being socially connected positively affected educational attainment and the probability of attending college. In contrast, scholars have also found that random assignment to peer groups in the context of a U.S. military academy may not necessarily result in the desired effect of improved educational outcomes (Carrell et al., 2013). In line with the current paper's focus on college bound friends, researchers have also found that college-oriented peers influence college enrollment decisions (Wells et al., 2013). Moreover, observational and quasi-experimental studies have found that high-achieving peers can also boost grade point averages once students are in college (Carrell et al., 2009; Fletcher and Tienda, 2009; Sacerdote, 2001; Stinebrickner and Stinebrickner, 2006; Zimmerman, 2003). ${ }^{6}$ Although some research has undermined the acting White hypothesis as a predictor of racial achievement gaps (Ainsworth-Darnell \& Downey, 1998), the burden of acting White may still apply in some school settings, especially those with high interracial contact and inequality (Fryer \& Torelli, 2010; Tyson et al., 2005). Further, Tyson et al. (2005) argue that the burden of acting White is the manifestation of a general oppositional culture that only happens in schools with a particular sociodemographic mix. Still, despite facing systemic barriers to education, Black students may still interpret their marginalized social status in a manner that still yields academic success, especially with the help of significant others (O'Connor, 1997, 1999). ${ }^{7}$ Still, just because females may have more college bound friends does not necessarily mean that the association between college bound friends and college-going will be greater for them.

${ }^{8}$ The reason that I did not include those not in any type of college in outcomes $2-4$ was because the first outcome already took care of examining the overarching question of whether $\mathrm{CBF}$ affected enrolling in any college versus not enrolling in any college. Therefore, students 
who did not enroll in any college were included in at least this part of the analysis. In outcomes 2 - 4, I wanted to take a closer look at those who did enroll in college. I wanted to know whether $\mathrm{CBF}$ affected the paths that students took once they had enrolled in college.

${ }^{9}$ Pro-science climate includes whether the school has any of the following features: special focus on math or science, holds math or science fairs/workshops/competitions, offers pre-high school summer reading/math instruction for struggling $9^{\text {th }}$ graders, sponsors a math or science after school program, pairs students with mentors in math or science, brings in guest speakers to talk about math or science, takes students on math- or science-relevant field trips, tells students about math/science contests/websites/blogs/other programs, requires teacher professional development in how students learn math/science, requires teacher professional development in increasing interest in math/science, raises student math/science interest/achievement in another way, offers College Board AP courses on-site, offers incentives to attract full-time high school math or science teachers, and on-site AP offerings for Calculus AB, Calculus BC, Computer Science, Computer Science A, Computer Science B, Advanced Biology, Advanced Chemistry, or Advanced Physics.

${ }^{10}$ Ignorable treatment assignment holds where conditional on the observed covariates selection into treatment is unrelated to unmeasured variables that affect the outcome.

${ }^{11}$ I included school-level variables in the matching model to partially account for the clustered nature of the data (Arpino \& Mealli, 2008).

${ }^{12}$ Kernel matching ensures that treatment and control subjects with similar propensity scores are matched within a given bandwidth, in this case 0.09 (Heckman et al., 1998; Stuart \& Rubin, 2008).

13 The sensitivity analysis, summarized by Table 3 , allows me to assess how large an unobserved confounder, $U$, and its associated selection bias, must be in order to undermine the results, adjusting for observed controls. Here, I report the range of gammas where the statistically significant ATT became statistically insignificant (i.e., the 'kill zones') due to the unobserved confounder, $U$. The gammas $(\Gamma)$ are presented as odds ratios ranging between 1.00 and 2.00 in increments of 0.05 . To be clear, Mantel-Haenszel bounds assume that the unobserved confounder is perfectly correlated with the outcome, suggesting that these kill zones' represent conservative bounds on our treatment effect (DiPrete \& Gangl, 2004). That is, they represent scenarios where the effect of $U$ may be much stronger than we might expect a priori (J. E. Rosenbaum \& Harris, 2001).

${ }^{14}$ I ran sensitivity analyses for the gender-specific analyses (i.e., those found in Appendices C and D). Like the sensitivity analyses for the gender-neutral results, the sensitivity analyses of the gender-specific results (not shown here for space considerations) also reveal robust treatment effects.

15 As with the first sensitivity analysis, I only report these results for the combined female and male samples for the sake of space.

${ }^{16}$ For the sake of space I do not report results for the gender-specific results for models that use the alternative CBF specification.

${ }^{17}$ Also, see Fletcher, Jason M. and Stephen L. Ross. "Estimating the Effects of Friendship Networks on Health Behaviors of Adolescents." NBER Working Paper No. 18253 (2012). 